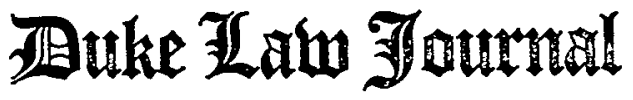

\section{LEASES OF EQUIPIIENT AND SOME OTHER UNCONVENTIONAL SECURITY DEVICES: AN ANALYSIS OF UCC SECTION 1-201(37) AND ARTICLE 9}

\begin{abstract}
Peter F. CoOgan*
Although leases, consignments, and sales of accounts and chattel paper annually result in commercial transactions involving many billions of dollars, the Uniform Commercial Code, which establishes the legal framework for these transactions, provides only a few sentences of guidance for the practitioner or judge seeking to determine whether a transaction denominated as a lease, consignment, or sale of accounts or chattel paper is in fact a secured transaction subject to all provisions of article 9 of the Code. In this Article, Mr. Peter F. Coogan, a consultant to the Committee To Review Article 9, examines in detail the provisions of section 1-201(37), which defines a security interest, and develops the history of this section. Concluding that the standards established by section 1-201(37) are lacking in the precision and clarity needed to make the difficult decision of when a transaction is indeed a true lease as opposed to a disguised secured transaction, Mr. Coogan considers whether leases-like sales of account and chattel papershould be subjected to some or all of the provisions of article 9 in order to make this determination. The author finds the application of these provisions to leases unsatisfactory; and he consequently turns to the standards of the Uniform Condi-
\end{abstract}

* Practitioner in Residence, Duke Law School, 1973-74; Lecturer, Harvard Law School; Visiting Lecturer, Yale Law School, 1958-63; Consultant to Committee To Review Article 9 of the Uniform Commercial Code, 1967-73; member, various other committees to consider changes in article 9, since 1953; principal author, P. COOGAN, W. Hogan, D. Vagts, Secured Transactions Under the UNIForm CoMmercial Code (1963-73) (in which this Article will appear as a new chapter). The writer acknowledges the help supplied by the following: William F. McCarthy, LL.B. 1970, Harvard University, Member of the Massachusetts Bar; and Charles W. Mooney, LL.B. 1972, Harvard University, Member of the Oklahoma Bar. This Article was originally planned as a joint effort; but because of pressures of time and geography, the final draft is entirely the work of the present author. However, it reflects contributions of Mr. McCarthy, who collaborated with the author on an assignment involving some difficult lease questions, and of Mr. Mooney, who satisfied his third-year writing requirement at Harvard Law School by doing a paper on leasing under the author's supervision. The Article represents only the personal views of the author. 
tional Sales Act, the tax bar, and the accounting profession in an effort to establish useful standards in this area. Finally, Mr. Coogan recommends that, at a minimum, a more direct treatment of this problem should be incorporated into the Code, indicating that the standards and precedents of the UCSA provide the best guidelines for determining whether a transaction is a true lease or a secured transaction.

\section{INTRODUCTION}

The Uniform Commercial Code ${ }^{1}$ contains only a few sentences with respect to leases, consignments, and sales of accounts and chattel

1. ALI, Nat'l CONF. OF COMM'rs on Uniform State Laws, UNIForm Commercial Code: 1972 Official TeXt with Comments and Appendix, 1972 Changes IN TEXT [hereinafter cited as UCC]. Reference will sometimes be made to the Code as the "UCC" or to section numbers alone. Where an earlier version is referred to, that fact is generally noted. Such earlier versions include: ALI, NaT'b CONF. OF COMM'RS ON UNIFORM STATE LAWS, UNIFORM COMMERCIAL CODE: MAY, 1949 Draft [hereinafter cited as MAY, 1949 DRAFT]; ALI, NAT'L CONF. OF COMM'RS ON UNIFORM STATE LAWS, UNIFORM COMMERCTaL CODE: OCTOBER, 1949 ReVision [hereinafter cited as October, 1949 ReVision]; ALI, Nat'L CONP. OF COMM'RS ON UNIFORM STATE LAWS, UNIFORM COMMERCIAL CODE: OfFicial Draft (Text and Comments ed. 1952) [heremafter cited as 1952 Official DrafT]; ALI, NaT'L CONF. OF COMM'RS ON UNIFORM STATE LAWS: RECOMMENDATIONS

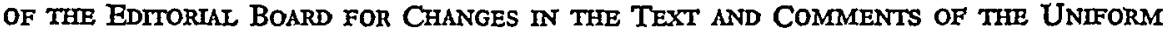
Commercial Code Official Draft, Text and Comments Edition (June 1, 1953) [heremafter cited as 1953 RECOMMENDATIONs], which inciuded changes approved at the enlarged Editorial Board meetings held on December 29, 1952, February 16, 1953, and May 21, 1953; AII, NaT'L CONF. OF COMM'rs on UNIForm STATE Laws, SUPPLEMENT No. 1 to THE 1952 OfFicial DRAFT OF TEXT AND COMMENTS OF THE UNIFORM COMMERCIAL CODE (January, 1955) [hereinafter cited as SupPLEMENT], which included amendments adopted by actions of the sponsors in their respective meetings in 1954; AII Nat'L CONF. OF COMM'RS ON UNIFORM STATE LAWS, 1956 RECOMMENDATIONS OF THE EDITORIAL BOARD FOR THE UNIFORM COMMERCIAL CODE thereinafter cited as 1956 Recommendations]; ALI, NAT'L CONF. of COMm'Rs on UNIFORM STATE LAWS, UNIFORM COMMERCIAL CODE: 1957 OFFICIAL TEXT WITH COMMENTS [hereinafter cited as 1957 OfFicial TEXT]; ALI, NAT'L CoNf. OF CoMm'rs on UNIFORM STATE LAWS: 1962 OfFICIAL TEXT wITH COMMENTS thereinafter cited as 1962 OFFICIAL TEXT].

In 1972 the sponsors approved with slight modifications the recommendations of the Committee To Review Article 9. In general, 1972 changes pertinent to this discussion are not especially significant; they are limited to a new seetion 9-114 (see p. 950 infra), a new section 9-408 (see p. 960 infra), and the elimination from section 9106 of the term "contract rights," with a necessary redefinition of the terms "account" and "general intangible." The definition of aecounts has been broadened somewhat by the 1972 changes. It now includes some pre-1972 Code contract rights. But it is still fairly narrow. The account must arise out of the sale or lease of goods or the rendering of services. For example, Stockbroker sells to Bank a receivable of $\$ 1,000$ owed by $A$ on A's purchase of a bond; or Food Machine Patent Owner sells the Bank's $\$ 10,000$ receivable against Food Packer for royalties on use of Patent Owner's Patent. Neither receivable is an account, and neither sale is within article 9. See generally Coogan, The New UCC Article 9, 86 Harv. L. Rev. 477 (1973). The 1972 changes have been adopted by Arkanșas, ARK. Sxat. ANN. \$§ 85-9-106, -114,

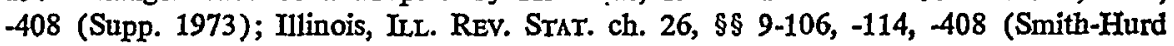


paper. It is true that one who obtains goods through a lease or a consignment or who obtains money through a sale of his accounts, has given his supplier or lender some assurances which would not have been available if the transaction had been one on open credit. But many leases, consignments, and sales of accounts have nothing to do with security under article 9-the article of the Code dealing with secured transactions. On the other hand, creation of a security interest is at times a principal motive of one or both of the parties in such commercial transactions. For example, it is not uncommon to find that what is called an ordinary lease or consignment is in substance a lease or consignment for security - that is, to most pre-Code and post-Code lawyers, "a conditional sale"-or that what initially appears to be an outright sale of accounts or chattel paper is in fact a secured borrowing. Each of these "sometime-security-interests" has been made subject in certain situations to some or all of the provisions of article 9. However, in most cases the Code provisions dealing with these devices provide no definitive guidelines for determining when such transactions in fact create security interests to which article 9 applies.

As a result, in the last decade or so, these sketchy provisions have been the subject of a rather significant amount of criticism by the authors of textbooks and law review articles, ${ }^{2}$ particularly with

Supp. 1973); North Dakota, N.D. CEnT. CoDe $\$ \$ 41-09-06,-13,-46.2$ (Supp. 1973); Texas, Tex. Bus. \& COM. CoDe $\$ \S 9.106$ (Supp. 1972); Virginia, VA. Code ANN. $\$ \S$ 8.9-106, 9.8-114, 8.9-408 (Supp. 1973).

HEREINAFTER THE FOLLOWING CITATIONS WILL BE USED IN THIS ARTICLE: UCSA];

UNIFORM CONDITIONAL SALES ACT (act withdrawn 1943) thereinafter cited as

G. GILMORe, Securty Interests IN Personal Property (1965) [hereinafter cited as GILMORE];

L. Jones, The Law of Chattel Mortgages and Conditional Sales (6th ed. R. Bowers ed. 1933) [hereinafter cited as JoNEs];

S. Williston, The Law Governing Sales of Goods at Common Law and UNDER THE UNIFORM SALES ACT (1st ed. 1909) [hereinafter cited as WILIISTON].

2. See, e.g., Hawkland, The Impact of the Uniform Commercial Code on Equipment Leasing, 1972 U. ILL. L. FORUM 446; Leary, Leasing and Other Techniques of Financing Equipment Under the UCC, 42 TEMPLE L.Q. 217 (1969); Peden, The Treatment of Equipment Leases of Security Agreements Under the Uniform Commercial Code, 13 WM. \& MARY L. Rev. 110 (1971); Stroh, Peripheral Security InterestsThe Expanded Net of Article 9, 22 U. Mramr L. Rev. 67 (1967). See also Comment, Selected Problems in California Chattel Leasing, 13 U.C.L.A.I. REv. 125 (1965); Note, Uniform Commercial Code Commentary-Secured Transactions, 8 B.C. IND. \& CoM. L. Rev. 101-13, 267-72, 764-70 (1964); 49 CoRNell L.Q. 672 (1964). Professor Hawkland's law review Article presents an analysis of twenty-one lease cases in which the court found a security interest and thirteen in which the court did not. It is very 
respect to leases and consignments. None of the writers would give very high marks either to the draftsmen of these Code sections or to many of the judges who had construed them. Candor requires one to add that kudos should be given neither to the draftsmen of some of the legal documents which have come before the courts nor to the counsel who failed to provide a record upon which an imtelligent decision regardimg article 9's applicability to these lease and consignment transactions could be made by the court. ${ }^{3}$

The legal and economic importance of both assignments of accounts and chattel paper and leases of equipment is self-evident to all involved in the worlds of finance and commerce. ${ }^{4}$ Annually many billions of dollars are imvolved in both outright sales of accounts and cliattel paper and in borrowings against such collateral. Also for reasons which shift from year to year as $\operatorname{tax}^{5}$ and accounting standards ${ }^{0}$

difficult to find that any common test was applied. In many cases essential information (e.g., market value at the time an option to purchase is to be exercised) is missing, and many of the leases summarized in the Article seem to have been drawn without analysis of what a lessor would want to prove if his leases were challenged. See Hawkland, supra at 469-81.

For criticisms of the Code's provisions on consignments, see R. DuEsenberg \& L. King, Sales and Bulx Transfers $\S 11.03(2)$, in 3 Bender's Service (1966); 4A J. Moore, R. Oglebay, F. KenNedy \& L. KIng, Collier on Bankruptcy $\Uparrow 70.18$ (14th ed. 1967); J. White \& R. Summers, The Uniform Commercial Code $\$ 22$ 4 (1972); Duesenberg, General Provisions, Sales, Bulk Transfers and Documents of Title, 27 Bus. LAw. 709, 731 (1972); Duesenberg, Consignments Under the UCC; $A$ Comment on Emerging Principles, 26 Bus. LAW. 565 (1970); Duesenberg, Consignment Distribution Under the Uniform Commercial Code: Code, Bankruptcy and Antitrust Considerations, 2 Valparaiso L. Rev. 227 (1968).

3. See Hawkland, supra note 2, at 469-81.

4. "No precise data are currently available on the leasing industry as a whole, but there seems to be little doubt that the value of goods now on lease is over $\$ 10$ billion." VALUE IINe INVESTMENT SuRveY, Oct. 12, 1973, at 227. It is interesting to note that in 1971 it was estimated that the following proportions of new equipment were being leased: $70 \%$ of computers, $60 \%$ of office equipment, $50 \%$ of railroad cars, $30 \%$ of passenger cars, $25 \%$ of aircraft, $15 \%$ of ships, and $10 \%$ of machinery and furniture and fixtures. Bus. WeEk, Sept. 4, 1971, at 42. Some transactions were no doubt "true" leases, others slightly disguised purchase-sale transactions.

5. Particularly while the Internal Revenue Code of 1939 was in effect, many taxpayers attempted to write off the cost of new equipment through "rent" payments under section 23(a)(1) which were generally substantially larger than comparable charges would have been for depreciation and interest on installment debt. When the 1954 tax code made available various forms of accelerated depreciation, the lease form became less desirable for this use though other tax considerations remained. Changes in the introduction of the investment tax credit in 1961, its repeal by the Tax Reform Act of 1969, and its reintroduction in a different form in 1971 all have influenced tax motives for use of a lease. See Baskes, Tax Planning for Lease Transactions, 1972 U. ILL. L.F. 482.

6. The extent to which a firm can, with accounting advantages, acquire the use 
change, the lease device is employed to enable lessees to obtain the use of hundreds of millions-perhaps billions-of dollars of equipment through a lease rather than an outright purchase. On the other hand, antitrust decisions over the last few decades have made a third type of "sometime-security" device, the consignment, less useful as a means for the distributor to control prices at the retail level; and the Code's simple inventory security procedures have largely displaced consignments as significant security devices. ${ }^{7}$ Yet, the consignment device is popular as a marketing tool for the very reason, that it is, from the standpoint of the supplier of goods, weak as a security device: there is no obligation on the part of the consignee to do more than remit the proceeds (less his commission) if he sells the goods or return the possibly shop-worn goods if he does not. As a result, the consignment continues to be frequently used in marketing where the retailer is unwilling to buy the consignor's goods outright but may be persuaded to display and sell the consignor's goods on a consignment basis since the consignee-retailer is not obligated to pay the price of goods.

Legal practitioners who work with the Code and judges who examine the resulting legal documents could reasonably expect that the draftsmen of the Code would have established some standards to determine when an article 9 security interest has been created, even though the transaction has been called a sale of accounts or chattel paper, a lease, or a consignment. At a minimum, references to pre-Code law spelled out in earlier drafts of what became article 9 might have been retained in the official comments. ${ }^{8}$ The Code's primary responses to the problem of defiming those transactions which create a security imterest are embodied in the sketchy provisions of sections 1-201(37) and 9-102. Section 1-201(37) reads:

[1] "Security interest" means an interest in personal property or fixtures which secures payment or perfornance of an obligation. [2] The retention or reservation of title by a seller of goods notwithstanding shipment or delivery to the buyer ... is limited in effect to a reservation of a "security interest". [3] The term [security interest] also includes any interest of a buyer of accounts, cliattel paper, or contract rights which is subject to Article 9... [4] The special property interest of a buyer of goods on identification ... is not a security interest but a buyer may also acquire a se-

of new goods through a lease has varied greatly from decade to decade. See, e.g., Wyatt, Accounting for Leases, 1972 U. ILL. L.F. 497.

7. See pp. 947-54 infra.

8. See pp. 936-41 infra. 
curity interest by complying with article 9. [5] Unless a lease or consignment is intended as security, reservation of title thereunder is not a "security interest" but a consignment is in any event subject to the provisions on consignment sales (Section 2-326). [6] Whether a lease is intended as security is to be determined by the facts of each case; however, (a) the inclusion of an option to purchase does not of itself make the lease one intended for security, and (b) an agreeinent that upon coinphiance with the terms of the lease the lessee shall become or has the option to become the owner of the property for no additional consideration or for a nominal consideration does nnake the lease one intended for security.

And section 9-102 provides:

(1) Except as provided in Section 9-104 on excluded transactions, this Article apphies

(a) to any transaction (regardless of its form) which is intended to create a security interest in personal property or fixtures including goods, documents, instruments, general imtangibles, chattel paper, or accounts; and also

(b) to any sale of accounts or chattel paper.

(2) This Article apphes to security interests created by contract including pledge, assignment, chattel mortgage, chattel trust, trust deed, factor's hen, equipinent trust, conditional sale, trust receipt, other ben or title retention contract and lease or consignwnent intended as security. This Article does not apply to statutory hens except as provided in Section 9-310.

Section 9-102, unlike 1-201(37), specifically limits article 9 security interests to those created by contract.

Section 1-201(37) uses five different techniques in determining when soine or all of its provisions apply to "sometime-security-interests." The first technique, presented in the second sentence of section 1-201(37), does not say positively that a seller's retention of title is a security interest (or "conditional sale") but rather that it is limited to a security interest. Three inferences may be drawn from this phrasing: (1) at least some reservations of title by a seller are security interests; (2) soine such reservations (e.g., a reservation of title by a seller in a section 2-326 "sale or return" or "sale on approval" where the buyer need pay the price only if he elects to keep the goods) may not constitute security interests; and (3) the reservation, if it does create a security interest, does not represent absolute ownership, but is limited to a kind of interest inore like that given to or retained by a secured party, with the purchaser acquiring an 
equity of which he can be deprived only in accordance with the debtor-protective provisions of part 5 of article 9. Which of the first two inferences is proper in a given case is less than clear unless one goes back to the earlier drafts of what ultimately became article 9 and to their predecessor, the Uniform Conditional Sales Act (UCSA), under which it was long settled that there is no conditional sale unless two eleinents converge: (1) the purchaser-debtor is obligated to pay an amount substantially equal to the purchase price; and (2) the purchaser-debtor thereby acquires, or has the option to acquire, the status of "owner" of the item conditionally sold. ${ }^{9}$ That law was long encrusted with refineinents: the seller could call himself a "lessor" or a "consignor"; but if the two elements set forth immediately above were present, the law treated him as a conditional vendor and his purchaser as a conditional vendee. We shall return to this idea at later points. ${ }^{10}$

The second technique used by the Code in determining when some or all of its provisions apply to "sometime-security-interests" is that used with respect to a sale of accounts. The words of sections 1-201(37) and 9-102 say that the interest of a buyer of accounts is a security interest; but 9-502(2) and 9-504(2) recognize that, in the case of a true sale of accounts, application of the remedy provisions of the Code would be impossible, since a true seller does not himself owe any obligation nor retain any property right against which a purchaser could proceed if the accounts or chattel paper do not pay out as anticipated. Therefore, in applying article 9 remedies to the case of a transaction cast as a sale of accounts or chattel paper, it is necessary to distinguish between a true sale and an assignment for security. This soinewhat oversimplified but useful approach will merit further discussion below. ${ }^{11}$

A third technique is used in applying article 9's provisions to a buyer's interest in goods not yet identified to a sales contract. Section 1-201(37) says that such an interest is not a security interest, although there exists both an interest in personal property and an obligation-a combination which seems to meet the requirements established in the first sentence of section 1-201(37) for the creation of a security interest. Here the buyer must otherwise create an ordinary article 9 security interest. This problem is somewhat beyond the scope of this paper, and this third interpretive technique which gives rise to it is mentioned here only for completeness.

9. UCSA \$ 1(2). See pp. 937-38 infra.

10. See pp. 938-39 infra.

11. See pp. $942-47$ infra. 
A fourth method is used to determine article 9's applicability to consignments. Under section 2-326, all consignments are subject to a public notice requirement, which can be satisfied alternatively by a filing under article 9. However, only those consignments intended for security are article 9 secured transactions.

Finally, a fifth technique is apphed to leases: either a lease is a "true lease" and is outside article 9, or it is one "intended for security" and thus is subject to all provisions of article 9. This determination must be made at the inception of the transaction.

To provide guidelines for the application of these various interpretive techniques, sections 1-201(37) and 9-102, in dealing with consignments and leases, imdicate that only those transactions which are "intended" to create security interests are covered by all of article 9's provisions. The application of any standard based on the intcnt of the parties, even with the best supplemental guidelines, is likely to be troublesome. ${ }^{12}$ Section 1-201(37) contains no guidelines for determining whether the parties to a consigninent transaction intended to create a security interest. Moreover, the cursory statement in the sixth sentence of 1-201(37) that the intent of the parties to a lease transaction is to be determined according to "the facts of each case" is not helpful. While one must question whether any standard other than intent of the parties would be preferable, it does seem that, as a minimuin, the Code's draftsinen inight well have given some indication as to what body of law provides the foundation against which consignments and leases should be evaluated and the intent of the parties judged. ${ }^{13}$

The problems inherent in such determinations and the Code's failure to set out effective standards for their resolution or to tell the reader where to look in other bodies of law for those standards can be demonstrated best by examining an actual case. In In re Royer's

12. See Levin, The Intention Fallacy in the Construction of Title Retaining Contracts, 24 Mrch. L. Rev. 130 (1925). No one would contend that third parties were bound by the clear intention of the contracting parties to use a device they call a lease if the effect created by the transaction is that of a sale. The test certainly must be applied in accordance with the outward appearance of the facts rather than in accordance with the intent held by one or both of the parties while creating effects contrary to those normally produced by the kind of instrument purportedly employed by the parties.

13. The comments to section 1-201(37) inention the Uniform Trust Receipts Act as the source of this proviso. That is true as to the term "security interest," but the Act had nothing whatever to do with the conditional sales type of problem with which most of section 1-201(37) is concerned. In the May, 1949 draft of the UCC, consignments for security were treated in subsequently abandoned section 7-304 and 
Bakery, Inc., ${ }^{14}$ a trustee in bankruptcy contended that a lessor was not entitled to the sales proceeds of equipment purportedly leased to the bankrupt. The trustee further asserted that this "lease" was really a conditional sales agreement which was not perfected under the Code because an article 9 filing had not been made. ${ }^{15}$ Referee Hiller properly noted that sections 9-102 and 1-201(37) would determine whether the lease agreement was subject to article $9^{16}$ and that no filing would be required if the instrument was a true lease. Under the agreement, Royer's, the lessee, had a right to terminate the agreement and to return the equipment on thirty days' notice with no obligation to pay except for rents due under the contract on the date of return.

Section 1-201(37) does not directly state what effect a lessee's right to terminate has upon the determination of whether the lease is one for security. ${ }^{17}$ The last sentence of 1-201(37) commands generally that the characterization of the lease as one for security be deter-

leases were handled in section 7-403, each provision being a modification of section $1(2)$ of the Uniform Conditional Sales Act. (While only section 7-403 of the UCC refers to the UCSA, it is obvious that that Act was also the origin for section 7304.) When the concepts, which had previously been treated separately, were incorporated in 1-201(37), the helpful comments to the abandoned sections were apparently overlooked. See pp. 938-39 infra.

14. 56 Berks County L.J. 48, 4 CCH Installment CRedit Guide $\{99,274$ (Ref. Bkcy. E.D. Pa. 1963). The referee in the case reported the following facts. Pursuant to a lease agreement, Royer's Bakery (Royer's) had possession of a breadwrapping machine which had an original list price of $\$ 4650$. The agreement required Royer's to pay monthly rent of $\$ 146$ for a term of thirty-five months but allowed the company to cancel the agreement by giving thirty days' notice, with no obligation other than that for rent then due. At the end of the term, Royer's could renew the lease for $\$ 465$ per year. The agreement also gave Royer's the right, at any time during the lease term, to purchase the machine for either the original hist price less eighty percent of the aggregate rentals previously paid by Royer's or tweuty percent of the list price, whichever was greater. When Royer's became bankrupt, the trustee sold the machine free and clear of liens. Claiming that it had at all times during the lease agreement retained title to the equipment, the lessor then sought to recover the proceeds of the trustee's sale. See id. at 49-50. See also United Rental Equip. Co. v. Potts \& Callahan Contracting Co., 231 Md. 552, 191 A.2d 570 (1963), where the Royer's result was reached despite the fact that under the lease, which was binding on the lessee for only one month, the lessee was not obligated to pay an amount substantially equal to the purchase price. Section 1(2) of the Uniform Conditional Sales Act codified pre-UCC law on this matter. 2-3 S. Williston, The LAW Governing Sales of Goods at Common LaW and under the Uniform Sales Act $\$ 336$, app. C (rev. ed. 1948).

15. See UCC \$§ 1-201(37), 9-102, -302.

16. 56 Berks County L.J. at 50-51. While section 9-102 sets forth the policy and coverage of article 9 , the ouly provisions for differentiating a lease for sccurity from a true lease are contained in 1-201(37).

17. See pp. $922-36$ infra. 
mined according to the "facts of each case." Those "facts," no doubt, should be limited to facts which show intent. But which facts? Is the right to terminate a relevant fact in this case? If so, under what body of law is its relevance assessed? Neither the present Code nor the cominents thereto provide an explicit answer.

In Royer's, Referee Hiller first struggled with the ambiguous phraseology of 1-201(37) and 9-102. After listing some tax law standards which he did not apply to the facts of the case, the referee decided that the lease was a "lease for security" and that, since no filing had been made, the lesser was not entitled to the proceeds of his leased goods. ${ }^{18}$ The surprising aspect of the referee's opinion was that in holding the transaction to be a conditional sale he attached no significance to the fact that the lessee had an option to terminate at any time, a term hardly characteristic of a sale and a crucial fact that under black-letter pre-Code law would have led to an opposite result. ${ }^{10}$ Furthermore, there is no indication that counsel for the lessor called the referee's attention to the significance of the option. Such an omission by both parties unust be attributed to the fact that the Code nowhere tells the reader what facts are critical in determining whether a transaction is one for security, or sometimes more to the point, in what other body of law one inay look for guidance. Referee Hiller's decision was both praised as "incisive" 20 and condemned as wrong ${ }^{21}$ by commentators. It would appear that any provision in a statute which misled a referee with more than a passing knowledge of the Code and which resulted in both praise and blame from his critics inerits reconsideration.

In this Article, we first take a quick look at the various types of provisions in article 9 as they bear on the problem of which Code provisions should be made applicable to different sometime-security interests. Next, because of the confusion evidenced by readings such as that accorded section 1-201(37) in the Royer's case, we explore the proper reading and interpretation of the literal words of section 1-201(37). The application of the rules of 1-201(37) and 9-102subjecting leases, consignments, and outright sales of accounts and

18. 56 Berks County L.J. at 53.

19. [A] lease which provides for a certain rent in instalments is not a conditional sale if the lessee can terminate ... even though the lease also provides that if rent is paid for a certain period, the lessee shall thereupon become the owner of the property. 2 S. WIIIISTON, supra note 14, § 336 at 299.

See also WinLISTON \$ 336, at 528 .

20. See E. Farnsworth \& J. Honnold, Cases and Materials on Commrrctal LAW 807 (2d ed. 1968).

21. See Comment, supra note 2; 49 CORNeLL L.Q. 672 (1964). 
chattel paper to some or to all of the provisions of article 9-are then examined in light of the section 1-201(37) discussion. Among these we treat first the Code's apparently simple handling of sales of accounts and next its treatment of consignments, each of which shows some of the choices which were available to the Code's draftsmen but which were not used with respect to leases.

Judging from the volume of cases and criticism, the majority of the problems arising under 1-201(37) and 9-102 involve leases, a fact which indicates that the Code's treatment of leases is not among its better accomplishments. Accordingly, we consider as a final item alternatives open to the draftsmen for remedying what appears to be a serious flaw. In some future rewriting of article 9, the UCC sponsors could adopt and express a clearer policy with respect to when a lease is one for security under article 9; but if they do so, consideration must be given to what the policy should be. Another alternative is to trust the parties to operate in a fashion which will reduce the room for error, and if they fail to do that, to trust the job to the courts without further statutory direction. In making this judgnent as to which course should be recominended to the Code draftsmen, consideration is given to the feasibility of adopting or adapting the alternative tests for identifying security interests provided by pre-Code conditional sales law, by certain incoine tax statutes and case law, and by the standards established for this purpose by the accounting profession.

Another purpose of this paper is to explore the extent to which counsel who only occasionally handle leasing transactions can follow a course of conduct which will usually make it unnecessary for the parties to decide at the inception of the transaction, so far as article 9 is concerned, whether the transaction is a true lease or a disguised secured transaction. (And this course of conduct is generally followed by lawyers who handle a relatively large volume of leasing transactions.) In exploring this question, we will necessarily suggest considerations to be kept in mind by a judge who must settle issues left unsettled by the parties; and hopefully, we will raise the question of whether future draftsmen of article 9 can, in fact, improve on the work-product of the group who produced sections 1-201(37) and 9-102.

Before we focus primarily on 1-201(37) and attempt to deterinine whether this provision wisely declares that certain "sometimesecurity-interests" are subjected to all provisions of article 9, and others to only some provisions, it is appropriate to review briefly the types of provisions which make up article 9 and which therefore might or might not be applied. 
We begin with requirements for public notice, noncompliance with which is the most common cause for attack on a security interest by hen creditors. Article 9's public notice requirements are found primarily in parts 3 and 4 . Public notice has not, however, always been a requirement of all chattel security systems. For example, immediately prior to the adoption of the Code, almost half of the then recent statutes governing assignments of accounts receivable excused public filing with respect to assignments of accounts. ${ }^{22}$ Other statutes of this type required filing. ${ }^{23}$ It should also be noted that public notice may be properly required under circumstances where no security interest is mvolved, as with the section 2-326 mandate that some form of public notice be made available with respect to all consignments, without regard to any security aspect. One could not rationally decide that a certain transaction should be treated as creating a security interest simply because good reasons exist for requirimg some form of public notice with respect to it. Where the legislation has not prescribed a form of public notice courts have seldom felt free to impose their own. ${ }^{24}$

A second class of provisions are those which relate generally to the enforceability of the arrangement between the parties and others. This category might be called the statute of frauds provisions, which, for article 9, are found in section 9-203.

A third class consists of the priority provisions that establish priorities among various persons who have placed themselves above the category of general creditors, such as buyers, lien creditors, and other secured parties. The pertinent provisions are contained primarily in part 3 of article 9.

The fourth, and probably the inost important, set of provisions with respect to any security systein encompasses those relating to the

22. At least fourteen pre-Code acts on assignments of accounts receivables did not require any form of public notice. See, e.g., Law of July 22, 1943, vol. 1, § 1 [1943] Ill. Laws 947 (repealed 1967). For an intensive review of pre-Code law, see Communication and Study Relating to Assignments of Accounts Receivable, in STATE OF N.Y. LAW REVISION COMM'N, REPORT, RECOMMENDATIONS AND STUdIES 351 (1946).

23. Ohio probably had the first modern accounts filing statute. See OHIO GEN. CODE ANN. tit. VII, ch. 2, div. III, § 8509-3 (1941). Another important statute was that of California. See CaL. CTv. Code $\S 3017(2)$ (West 1954). See also N.C. GEN. STAT. art. 14, $\$ 44-77$ (1945). Certain types of leases are occasionally required to be filed, without regard to any security aspects. See, e.g., CAI. Civ. CODE $\$ 2980.5$ (West 1954) (requiring that leases of livestock and other animate chattels be recorded). See also Federal Aviation Act $\S 503,49$ U.S.C. $\S 1403(a)(1)$ (1970) (requiring recording of "[a]ny conveyance which affects title to, or any interest in, any civil aircraft of the United States ....").

24. At most, courts may have occasionally stretched a statute to require filing for a security device, the ultimate effect being the same as that which would result if the device were strictly covered by the statute. 
remedies of the respective parties in the event that the debtor is unable or unwilling to meet his obligations, thereby forcing the secured party to resort to foreclosure or some other method of disposing of the collateral in order to pay himself out of the proceeds of its disposition. That disposition, however, must be made only in accordance with a set of rules gradually evolved over the centuries to protect the debtor's "equity of redemption" if any he has, even if such disposition slows down the secured party's action in collecting his debt. ${ }^{25}$ Any surplus must be turned over to the debtor. Ordinarily a corollary is that the secured party has a right to collect out of other assets of the debtor the difference between his debt and the amount of the proceeds received from disposition of the collateral.

Remedy provisions of any security systein presuppose the existence of the two elements set out in the first sentence of section 1-201 (37) as primary requisites of a security interest: (a) an obligation to be secured and (b) a property interest which can be disposed of, with its proceeds being applied towards the discharge of that obligation. Ordinarily a debtor is not permitted to waive in advance of a default the rights given him by law. There can be no mature security system without a body of law regulating the rights of the parties where the secured party resorts to the collateral to collect the debtor's obligation. Where the legislature has not prescribed the rules, the courts have done so.

We refer to these as the remedy provisions. It would not make sense to say that article 9 should apply to a particular class of transactions simply because some form of public notice, or some form of statue of frauds provisions, or some form of priority rules would be a good thing. But it might very well make sense to determine whether article 9 should or should not apply based on the appropriateness of applying its remedy provisions. With this analysis in mind, we return now to a question of the inethods by which the Code sometimes applies some, and sometimes applies all, provisions to certain categories of transactions.

25. For the story of how courts modified the common law of strict mortgage, see G. Osborne, Handbook on tHe LAW OF Mortgages $\$ 6$ (2d ed. 1970). There are no comparable instances where the courts imposed their own rules as to public notice. See generally R. TURNER, EQUITY OF REDEMPTION (1931). A great equity scholar, E. Durfee, says: "Relief from forfeiture, ultimately labeled redemption, is the center of the chancellor's system, the nucleus of the atom." $1 \mathrm{E}$. DURFEE, CASES on Security 15 (1951). See also id. at 20. For convenience we use the phrase "debtor's equity of redemption" rather freely describing the bundle of protective provisions built up by the courts and the statutes in an attempt to save for the debtor any excess of the fair value of his collateral over the amount of the debt secured. 


\section{SECTION 1-201(37)}

Section 1-201(37) singles out five particular situations-(1) transactions involving a seller's title reservation (of which the ordinary conditional sale is a common example); (2) sales of accounts or chattel paper; (3) property interests of buyers in goods identified to a contract; (4) reservation of property by consignors; and (5) reservation of property by lessors-in which a security interest may or may not be created. However, before separately discussing each of these situations, a general survey of 1-201 (37) is necessary.

\section{How To Read Section 1-201 (37)}

Section 1-201(37) now consists of six sentences. For a number of years, the UCC draftsmen and sponsors considered section 1-201 (37) complete with only the first two sentences. ${ }^{26}$ Pennsylvania for a number of years operated with only the first three sentences. ${ }^{27}$ Sentences beyond the third becanie part of a working statute for the first time when the Code became effective in Massachusetts ${ }^{28}$ on October 1, 1958-over nine years after the first draft of what is now article 9 appeared in May, 1949. In addition to operating for many years without even the third sentence, section 1-201(37)-though dealing with subject matter which is largely that of article 9-was physically located in article 1 and was thereby placed within the jurisdiction of article 1's draftsmen and advisors. ${ }^{29}$ The liaison between the draftsmen of these two articles was less than perfect. Thus, the fifth and sixth sentences, which essentially are commentaries on the retained

26. See notes pp. 936-42 infra. In a $1949 \mathrm{draft}$ only the first sentence appeared in definitions applicable to what is now article 9. See MAY, 1949 DrAFr \& 1-201(37). Section 1-201(37) of a 1950 draft contained essentially the first two sentences of the present version. See Spring, 1950 DrafT. By 1952, essentially the present sentence on rights of buyers of accounts had been added. See 1952 OfFICIAL Draft. The fourth sentence (now the fifth sentence) was first published in 1955. See SUPPLEMENT. Neither the present sentence on security interests of buyers nor the sixth sentence appeared until the following year. See 1956 Recommendations. The principal parts of the 1956 Recommendations of the Editorial Board were incorporated into the 1957 version of the UCC. See 1957 OfFICIAL Text.

27. Until 1963, when Pennsylvania adopted official amendments approved after 1952, that state operated under the 1952 text. See Act of Aug. 24, 1963, PA. Laws 1213, \& 1, amending Act of April 6, 1953, \& 1-201(37), [1953] Pa. Laws 26 (codified at PA. Stat. ANN. tit. 12A, \$1-201(37) (1970)).

28. Act of August 20,1957, ch. 765, § 1, Mass. Acts \& Resolves (effective Oct. 1, 1958) (codified at Mass. ANN. Laws ch. 106 (1963)).

29. The names of the members of the various subcommittees are set out in the 1972 version. See 1972 Official TeXt, at XVI-XVII. Each article or group of articles had its advisors at various stages of drafting. See, e.g., MAY, 1949 DrAFT \& 7-101, Comment. 
title which is the subject of the second, are inserted after two intervening sentences on foreign topics. As a result of this erratic development of section 1-201(37), it is neither a tightly organized nor easily readable section. Professor Gilmore has stated that

[t]here is no creditable explanation for the random arrangement of $\S 1-201(37)$. From time to time someone would think of a new point and a new sentence would be thrown into the hopper. Fortunately, no real harm seems to have been done; except for its untidy appearance and the bewilderment it may cause the unfamiliar reader, the ramshackle structure holds together reasonably well..$^{30}$

One might add that the section "holds together reasonably well" only if compared with other ramshackle structures. ${ }^{31}$

These structural failings have resulted in some unusual methods of applying the statute. For example, in a recent Oregon case ${ }^{32}$ the court was called upon to determine whether the parties had created a conditional sale or a lease agreement. The court, while noting that the message of section 1-201(37) on the sale-lease question is difficult to understand, asserted that the section makes sense if one first reads clause (b) of the sixth sentence and then reads the introductory ("facts of each case") clause of that sentence only if a lease for security is not created under the terms of clause (b). Although this construction of the sixth sentence has some apparent grammatical basis and probably would result in a proper decision in most cases, as it did in the Oregon case, it caused the referee deciding In re Royer's Bakery, Inc.

30. 1 GILMORE $\$ 11.1$, at 334. Since the early fifties, the writer has been a member of the committee responsible for evaluating suggested changes in article 9, but he cannot recall any systematic reexamination of section 1-201(37). Professor Gilmore's criticism properly applies to the addition of the fifth aud sixth sentences at the end of the section rather than after the second sentence, to which the fifth and sixth relate.

31. The position of 1-201(37) is a large part of the problem. Although this provision deals with article 9 subject matter, section 1-201(37) is technically outside the jurisdiction of the committees which have dealt with that article; and those committees have, therefore, been understandably reluctant to poach on the territory of another committee.

32. Peco Inc. v. Hartbauer Tool \& Die Co., 262 Ore. 573, 500 P.2d 708 (1972). In applying 1-201(37), the court noted that

[a]t first glance the provisions of . . . section [1-201(37)] may be somewhat confusing, probably because they are stated in the inverse order of importance. However, upon a careful reading of the entire section it is clear that the first question to be answered is that posed by clause (b) - whether the lessee may obtain the property for no additional consideration or for a nomiual consideration. If so, the lease is inteuded for security. If not, it is then necessary to determine "by the facts of each case" whether . . . the fact that the lease contains an option to purchase "does not (of itself) make the lease one intended for security." Id. at 575, 500 P.2d at 709-10, quoting ORE. REV. STAT. \$ 71.2010(37) (1969). 
to reach an incorrect conclusion. ${ }^{33}$ The Royer's court found that the parties had created an option in the lessee to purchase at a nominal consideration at the end of the lease term; therefore, under clause (b) it was determined that a security interest had been created and the rest of section 1-201(37) was ignored. The ignored portions of the section included its two most significant provisions-the second sentence, which in its sketchy form is the primary reference to conditional sales law, and the introductory clause to the sixth sentence, which says that each lease will be judged "by the facts of each case." Application of these provisions in the Royer's case would have dictated a different and proper result. By applying only clause (b) of the sixth sentence, the court in Royer's ignored the key fact that the lessee had an absolute right to terminate the lease-leaving no obligation to pay an amount substantially equal to the purchase price, a characteristic that has long been a prerequisite of a conditional sale under pre-Code law. It is suggested that such bizarre and imcorrect results are more likely to be avoided if one reads 1-201(37) in a inore normal order-the order in which it is written.

The First Sentence-“ $A$ security interest is an interest in personal property or fixtures which secures payment or performance of an obligation."

The first sentence of section 1-201(37) states two universal eleinents which inust exist in combination for a security interest to be created: (1) a property interest and (2) an obligation. But this sentence states too much. Will this combination of any obligation and any interest in property create a security interest? The answer is clearly no. Section 9-102 limits the application of article 9 to security interests created by contract. Thus, security interests ("liens") may be created by statute, ${ }^{34}$ by tort law, ${ }^{35}$ or by equitable doctrines, ${ }^{36}$ yet such interests are not article 9 security interests unless and until the

33. Referee Hiller has demonstrated that he has prior experience with lease-conditional sales. See Hiller, Security Aspects of Chattel Leases in Bankruptcy, 34 FordHAM L. Rev. 439 (1966). It should also be pointed out that the conditional sales law of Pennsylvania, the state whose law applied, was unique with respect to its bailment lease. See 3 JONES $\S 960$.

34. For the general exclusion of security interests created by statute, see UCC $\S$ 9-102(2). Particular liens, including certain liens created by statute, are excluded by section 9-104.

35. Id. \& 9-104(k).

36. E. FARNSWORTH \& J. HonNold, supra note 20, ch. 11, 84 (conflicts among surety, creditors, and financing banks), reprinting in part Pearlman v. Reliance Ins. Co., 371 U.S. 132 (1962), American Fidelity Co. v. National City Bank, 266 F.2d 910 (D.C. Cir. 1959), Royal Indem. Co. v. United States, 93 F. Supp. 891 (Ct. Cl. 1950). 
parties contractually confirm a noncontractual obligation or confirm a non-Code interest througl a Code device. ${ }^{37}$

The combination of property imterests which would seem to qualify as security interests under the first sentence of 1-201(37) are further reduced by later provisions in 1-201(37) itself. For every seller's retained title, the subject of the second sentence, there is a property interest in the seller and some obligation on the part of the buyer-even in a "sale or return" or a "sale on approval," there is at least a duty to pay if the goods are not returned. Yet the second sentence warns that not every seller's retained title is a security interest. The fourth sentence indicates that a buyer's propery interest in goods on identification to a sales contract does not, without nnore, create a security interest. Furthermore, even though the second sentence of section 1-201(37) provides that a seller's retained title may give rise to a security interest, according to the fifth sentence a mere reservation of title by a lessor or by a consignor is not a security interest. While the draftsinen were grammatically correct in putting the emphasis on the property concerned, it would have been inore helpful to a person in the position of the referee in the Royer's case if the distinction had been made in terms of the obligation secured. Surely the property interest of a seller, buyer, lessor, or consignor is not disqualified from forming the basis for a security interest. Instead, in each case it is the character of the obligation secured which nakes a security interest inappropriate. ${ }^{38}$ The first sentence of section 1-201(37) treats the obligation secured and the property interest which secures it equally, but this parity is soon lost. Interests in property are classified and subclassified under the label of "collateral" in sections 9-105, 9-106, and 9-109. Obligations, on the other hand, are not directly classified anywhere in the Code. ${ }^{39}$ Although it is difficult to conceive of a security agreenent which does not describe the obligation secured

37. In Hurley v. Dillon, 43 Okla. B. Ass'n J. 3419, 11 UCC ReP. SERv. 1053 (Ct. App. 1972), defendant argued that his method of enforcing a landlord's hen created by the lease was proper because bis action would have been justified under article 9. The court recited section 9-104(b) in holding that landlord liens were outside article 9. Contra, In re King Furniture Co., 240 F. Supp. 453 (E.D. Ark. 1965). The better view would seem to be that the parties are free to create by contract an interest to secure an obligation which the law automatically gives some priority, but that they must do so in the manner required under article 9.

38. Professor Gilmore queries whether a nonmonetary obligation can support a security interest. 1 GILMORE $\$ 11.1$, at 334 (1965).

39. However, the Code does draw some distinctions based on the origin or type of obligation secured thereby. See UCC $\$ \S 9-107,-301(2),-302(1)(d),-312(3)-$ (4) (indicating that special rules may apply where the obligation represents the purchase price of the collateral). 
thereby, the Code section which tells us when a security interest is enforceable, section 9-203, does not require that the obligation be described at all. Further, section 9-402 requires that a financing statement "indicat[e] the types, or describ[e] the items of collateral." Again, the obligation need not be indicated or described. We may observe that although the Code does not say so, there does exist a significant distinction in the nature of the debtor's obligation among the different transactions covered by 1-201(37). ${ }^{40}$ In the typical case covered by the first sentence, the obligation is primarily monetary: a borrower has obligated himself to repay a loan and has secured that obligation with an assignment of accounts, with a chattel mortgage type of security interest on some equipment, or with a trust receipt type of obligation secured by his inventory; or in the case of a conditional sale, the debtor has obligated himself to pay an amount substantially equivalent to the price of the goods. In the more unusual type of transaction, the obligation may be primarily nonmonetary, or the "debtor" may have a choice between paying inoney or returning goods. For example, a seller's obligation to a buyer is to deliver goods, not to pay money. A consignee's obligation is to return the goods or to pay money. A lessee's obligation is to pay rent and to return the leased item. The remedy provisions of article 9 are reasonably applicable only where there is a direct monetary obligation and an acquisition by the debtor of rights in the collateral. ${ }^{41}$ But whether or not there is a direct

40. The obligations behind some title retentions create security interests; the obligations behind other title retentions do not. The conditional vendee's duty to pay for goods conditionally sold supports a security interest; the obligation of a lessee to pay rent and the obligation of a consignee to return consigned goods do not. See UCC \$ 1-201(37).

41. Section 1(2) of the UCSA provides (a) that the lessee or consignee be obligated to pay an amount equal to the purcliase price and (b) that it is agreed that as a consequence he becomes the owner or has the option to become the ownera double requirement not confined to the UCSA or to cases decided under it. That Act was never in effect in Massachusetts, but the court arrived at a similar conclusion in DaRocha v. Macomber, 330 Mass. 611, 116 N.E.2d 139 (1953). The necessity for that obligation is restated by Judge Friendly in Allen v. Colien, 310 F.2d 312 (2d Cir. 1962), a case decided under UCSA section 1(2). Such a requirement was also read into section 23(a)(1)(A) of the Internal Revenue Code of 1939, which uses no such language. See Western Contracting Corp. v. Commissioner, 271 F.2d 694 (8th Cir. 1959); Breece Veneer Panel Co. v. Commissioner, 232 F.2d 319 (7th Cir. 1956); Benton v. Commissioner, 197 F.2d 745 (5th Cir. 1952). There are a few cases which have either failed to recognize the significance of such a requirement or have not felt bound by the rule. At least two of the most frequently cited cases involved acts which were primarily recording statutes. It is quite possible that a state court might require that a transaction be subject to certain public notice requirements where the same tribunal would not have held that the situation gives rise to the respective rights of the parties on default under a chattel security statute. See 
monetary obligation to be secured, the debtor may elect to convert the transaction into a typical secured transaction by agreeing to pay an amount substantially equivalent to the purcliase price.

To summarize, the first sentence of section 1-201(37) clearly states that both a property interest and an obligation secured thereby are essential in order for a security interest to exist. However, while both inust exist to create a security interest, the inere presence of both of these elements is not in and of itself sufficient for a security interest to exist. We must look to logic and history to determine which obligations suffice to create a security interest.

The Second Sentence- "The retention or reservation of title by $a$ seller of goods . . . is limited in effect to a reservation of a security interest."

The second sentence states that a seller's retained title may be the kind of property interest on which a security interest may be based. The first sentence of 1-201(37) says that the seller is the beneficiary of the buyer's obligation to pay the price. And the second sentence, with its title retention language, refers us to a long-established body of conditional sales law which requires that the vendee be obligated to pay an amount substantially equal to the purchase price. To determine the rights of a seller and the obhgations of a buyer, we must look to the article on sales, starting with sections 2-106 and 2-401. In an ordinary sale there is a monetary "obhgation" to be secured, and the parties are free to agree that title is not to pass until the obligation is paid. However, in a "sale or return" or a "sale on approval," the vendor retains the necessary property interest; but the vendee can relieve limself of the obligation to pay the price by returning the goods. Therefore, what appears to be the ambivalent language of the second sentence is necessary to accommodate within the Code's definition of security interest both of the above transactions, which were treated as security interests under traditional sales law.

The second sentence further indicates that, in accordance with well establislied pre-Code conditional sales law, wliat may appear to be

First Nat'1 Bank v. Phillips, 261 F.2d 588 (5th Cir. 1958). See also Beckwith Mach. Co. v. Matthews, 190 Md. 182, 57 A.2d 796 (1948). See generally 1 S. WIILISTON, The LaW Governing Sales of Goods at Common LaW and Under the UNIForm SALEs ACT $\S 336$, at 782 (2d ed. 1924). Practitioner Stroh has questioned the necessity for an obligation to pay the purchase price. See Stroh, supra note 2, at 79 . His argument might be persuasive on the question of whether some form of public notice ought to be required where the debtor's rights exceed his obligations. His argument is unsound as to whether article 9 should be required for all purposes in such cases. 
full title held by a conditional vendor is limited to a security interest. ${ }^{42}$ The law only gradually recognized that a conditional vendee, not unlike a chattel inortgagee or real estate mortgagee, had acquired an equity in the property of which he could be deprived only in accordance with rules which protected his equity of redemption. ${ }^{43}$ It became equally well established over many decades that if a transaction bearing the cloak of a "consignment" or a lease was in reality a conditional sale, the deliveror's retention of title was not the almost complete retained title of a consignor or lessor but the more limited title of a conditional vendor. ${ }^{44}$ Accordingly, the usual conditional sales rules as to public notice and protection of the deliveree's equity of redemption likewise applied to such instruments. ${ }^{45}$ The decision in most condi-

42. The development of the security aspect of the conditional sale is reviewed in 1 GILMORE $\$ \S 3.1-.8$. The second sentence of 1-201(37) reminds us that the conditional vendor, like a chattel mortgagee, has a security interest in the collateral. The idea that the conditional vendor remained the "owner" of conditionally sold goods died hard. But see In re Yale Express Sys., Inc., 384 F.2d 990 (2d Cir. 1967).

43. See generally 3 JONES $\S \S 1378,1382-90,1394-95$.

44. Until the 1956 Recommendations of the Editorial Board, the second sentence -in slightly differing forms in various drafts-contained the words "or consignor" after the word "seller." One who reads the former sentence too quickly would get the impression that the draftsmen were attempting to make all consignments into security interests. This possible interpretation of what became section 1-201(37) was belied by the May, 1949 draft of section 7-304: this provision clearly differentiated between an ordinary consignment, which was subject only to the public notice requirements of section 2-326, and a purported "consignment" in which the consignee agreed to pay the purchase price whether or not he disposed of the goods. Under pre-Code law, the consignor's interest was generally good without any public notice. Ludvigh v. American Woolen Co., 231 U.S. 522 (1913). See generally R. BRown, THE LAW of Personal Property $\$ 79$ ( $2 \mathrm{~d}$ ed. 1955), which notes that states with so-called "signposting" statutes were the exception. See note 103 infra. Section 2-326 expanded the rights of the consignee's creditors at the expense of the consignor, unless the consignor complied with that section's requirements. Section 2-326 was the subject of considerable discussion by the New York Law Revision Commission. See REPORT or New York Law Revision Commission Leg. Doc. 65(c), at 102 (1955). The older language is consistent with the $2-326$ concept that the consignor's interest, being subject to claims of the consignce's creditor unless the consignor satisfies the public notice provisions of 2-326, is something less than a "true" lessor's interest, which is free from claims of the lessee's creditors. However, the more detailed provisions of former section 7 304 more accurately reflect the fact that a consignor can have no full-fledged security interest unless, as summarized in UCSA section 1(2), there is an obligation for the consignee to pay an amount substantially equal to the purchase price in exchange for ownership. For a more complete history, see pp. 936-42 infra. As the result of the criticisms by the New York Law Revision Commission, the UCC Editorial Board recommended deleting the words "or consignor" from section 1-201(37). See 1956 RECOMMENDATIONS.

45. See generally 4A ColIIER ON BANKRUPTCY, supra note 2 , $\$ 70 \mathrm{a}(5)$, I 70.18 ; 1 GIIMORE $\$ 11.2$. The Code's undefined "lease for security," "consigninent for security," and seller's reservation or retention of title are more naturally referred to as conditional sales. We therefore use that term. 
tional sale-lease cases or conditional sale-consignment cases can rest on this second sentence of section 1-201(37) without recourse to language which first became effective law many years after the drafting had been considered complete. ${ }^{40}$ But since the Code provides no other standards for identifying a security interest, where such recourse is necessary the reader must find his own way to the sizeable body of conditional sales law which that one sentence incorporates. ${ }^{47}$

But why do we look at the old conditional sales law to interpret section 1-201(37)? A principal draftsman of article 9, and one of its most illuminating coinmentators, reininds us that

[t]he Code, like the earlier Uniform Acts which it supersedes, is frequently written in a sort of shorthand. The key which unlocks its cipher is the pre-Code law. In a presently unknowable number of instances, interpretation of the Code's provision will require a direct reference to that law. ${ }^{48}$

Thus, pre-Code conditional sales laws offer a rich source of precedent froin which the ineaning of the second sentence of section 1-201(37) may be gleaned. ${ }^{49}$ This second sentence, then, tells us only that some

46. Pennsylvania adopted the Code in 1953, effective July 1, 1954. Act of April 6, 1953, [1953] Pa. Laws 3 (codified at PA. Stat. ANn. tit. 12A (1954)). While the addition of the sixth sentence was included in the 1956 Recommendations, those recoinmendations were not acted upon by the sponsors until the 1957 text was formulated. See 1957 Official TeXt \& 1-201(37). After 1953 Pennsylvania did not adopt amendments until 1963. In the meantime, Massachusetts adopted the UCC in substantially its present form. Act of August 20, 1957, ch. 765, § 1, Mass. Acts \& Resolves (effective Oct. 1, 1958) (codified at Mass. Laws ANN. ch. 106 (1963)).

47. The official comment to section 1-201(37) of the Code refers only to the Uniform Trusts Receipts Act as the source of the term "security interest" without any reference to borrowing concepts from the Uniform Conditional Sales Act, the lineal ancestor of the consignment-lease-sale concept. When this concept was embodied in later abandoned section 7-403, its ancestry in the UCSA was clearly indicated. See MAX, 1949 DRAFT $\$ 7-403$, Comment 1 . This history was apparently inadvertently dropped.

48. 1 GILMORE viii. The same author states this idea differently:

In carrying ont their self-proclaimed mission of simplification, the Article 9 draftsmen worked, of necessity, out of the past. Draftsmen do not have a crystal ball for peering into the future. What they can do, in a legal context, is to read the old cases and the existing statutes and reduce the past to a sort of order. Gilmore, Security Law, Formalism and Article 9, 47 NEB.

L. REV. 659, 671 (1968).

49. The literature on the problem of when a consignment or a lease is a conditional sale is plentiful. For perhaps the most complete discussion of pre-Code conditional sales law, see 3 JoNEs $\$ \S$ 952-76. For an extended discussion of the distinction betwcen a conditional sale and a lease, see WILLISTON $\$ 336$. For a brief discussion of conditional sales and a somewhat lengthier treatment of what the UCC calls consignments and leases for security, see R. BROWN, supra note $44, \S \S 72,79$. See also 4A COLLIER ON BANKRUPTCX, supra note 2 , § 70.18(5); 1 GILMORE $\$ \S 3.1-8$; L. VoLD, HaNdBoOK of the Law of Sales 326-30 (2d ed. 1959); Annot., 175 A.L.R. 1366 (1948); Duesenberg, Antitrust Considerations, supra note 2. 
title retention by a seller (for which the parties are allowed to contract for any reason) can constitute a security interest; but no title retention by a seller can be inore than a security interest. The sentence imphes that a seller's title retention without more is not a security interest. To determine where the line is drawn, we go to pre-Code conditional sales law, which fortunately was clearly summarized in the few sentences of the Uniform Conditional Sales Act's section 1(2).

The Third Sentence: "The term [security interest] also includes any interest of a buyer of accounts or chattel paper which is subject to Article 9."

The concept that a sale of accounts and chattel paper creates a security interest does not fall within traditional concepts of chattel security law because the seller of accounts or chattel paper has no remaining property interest and no obligation to the purchaser. Nor, in the absence of a special agreement, is there any obligation on the seller to make up the difference between the purchase price received by him and the amount collected by the buyer. Likewise, in the absence of a special agreement, the seller is not entitled to any surplus received on collections in excess of that price. Consequently, in the case where accounts or chattel paper do not pay out as anticipated, there is no retained property interest against which the purchaser can proceed for satisfaction. This third sentence of section 1-201(37) shows, in bold language, that the draftsmen desired to bring under the wing of article 9 a transaction which did not meet traditional concepts of chattel security as expressed in the first sentence of 1-201(37). Without any requirement that we look for a security motive or intention on the part of seller or buyer, this sentence arbitrarily decrees that the interest of a buyer of accounts or chattel paper is a security interest. ${ }^{50}$ But when read in the light of the necessary limitations on remedies applicable to true sales of accounts and chattel paper, it is evident that calling the interest of a buyer of accounts or chattel paper a security interest is forced terminology indeed. ${ }^{51}$

The Fourth Sentence: "The special property interest of a buyer of goods on identification of such goods to a contract for sale under Section 2-401 is not a 'security interest', but a buyer may also acquire a 'security interest', by complying with Article 9."

50. See also UCC \$ 9-102.

51. This artificial definition of security interest requires other equally artificial definitions. In section 9-105, the buyer of accounts is a "secured party" and the seller is a "debtor." The property purchased by the secured party is nevertheless, the "collateral" of the debtor. 
It has heretofore been demonstrated that the obligation secured under the fourth sentence of section 1-201(37) is not the payment of money but the seller's obligation to supply goods. ${ }^{52}$ This fact raises the question as to whether a security interest can secure a nonmonetary obligation. ${ }^{53}$ In the fourth sentence of section 1-201(37), the Code is apparently telling us that to be enforced, a security interest in the seller's obligation to deliver goods must be one created by a separate contractual article 9 security interest. For example, $S$ agrees that B may recover partial payment or damages for nondelivery by selling S's remaining interest in the bought goods. As mentioned earlier, this sentence again demonstrates that the first sentence of 1-201(37) cannot be taken quite at its face value. There exists in the situation described by the fourth sentence a property interest and an obligation, but without nore, not a security interest.

The Fifth Sentence: "Unless a lease or a consignment is intended as security, reservation or title thereunder is not a 'security interest' but a consignment is in any event subject to the provisions on consignment sales (Section 2-326)."

The language of the fifth sentence also limits the broad language of the first sentence of section 1-201(37). It might be thought that, by the flat words of the first sentence, retention of title in every lease and every consignment is a security interest. The lessor and the consignor have a species of property interest-a retaimed title to the property bailed to the lessee or consignee. The lessee has an obligation to pay rent, ordinarily in money, and to return the property; the consignee has an obligation to return the property, or if he sells it as agent of the consignor, to pay over the proceeds. Why do the property imterest and the obligation in each case fail to create a security interest under the first sentence? Section 1(2) of the UCSA tells us that there is no conditional sale (a) unless there exists an obligation to pay an amount substantially equivalent to the value of the property involved and (b) unless as a result thereof the obligor becomes or has the option of becoming its owner. In the ordinary lease or consignment arrangement, these requisites are missing.

The fifth sentence of section 1-201(37) flatly says that neither the lease nor the consignment creates a security interest, unless the

52. See p. 926 supra. See 1 GILMORE $\S 11.1$. It is clear that there must be "some obligation" which underlies or supports the interest; this obligation will uormally be a money debt but could conceivably be something else ("payment or performance"). Id. at 334 .

53. See notes $40-41$ supra and accompanying text. 
parties intended to create a security interest. The fifth sentence was not added until the Code was revised in $1954 . .^{54}$ The sixth sentence was inserted even later in 1956. The reasons given in 1956 for the addition of these sentences do not explain why the conditional salelease and conditional sale-consignment transactions were not, as the draftsmen had earlier assumed, already considered to be covered as part of the conditional sales law which was incorporated by the first and second sentences of section 1-201(37). ${ }^{55}$ Soine history outlined later will be helpful in answering this question. ${ }^{56}$

The Sixth Sentence: "Whether a lease is intended as security is to be determined by the facts of each case; however, (a) the inclusion of an option to purchase does not of itself make the lease one intended for security, and (b) an agreement that upon compliance with the terms of the lease the lessee shall become or has the option to become the owner of the property for no additional consideration or for a nominal consideration does make the lease one intended for security."

This final sentence of section 1-201(37) has been read in a most unusual way by some courts. As already noted, ${ }^{57}$ an Oregon court suggested that this sentence should be interpreted by first reading clause (b) and only thereafter reading the preceding part of the sentence if the answer to the issue propounded in clause (b) is negative. Such a reading not only ignores the simple fact that English should be read in the same order as it is written, but, as was seen above, ${ }^{58}$ may also lead a court to classify a true lease as a conditional sale, solely because the lease agreement contams an option to purchase for nominal consideration, and notwithstanding the presence of other terms (e.g., the lessee's option to terminate) which indicate the presence of an ordinary lease rather than a conditional sale. To avoid such a result, the first sentence

54. See SUPPLEMENT 4. This supplement slightly modified the language of the first sentence. The principal change in the second sentence was the elimination of the words "or consignor." The fifth sentence, beginning "Unless a lease or consignment is intended as security," was first added. The sentence on accounts deleted the word "financing" before the word "buyer" and added the phrase "which is subject to Article 9." See id. § 1-201(37). The sixth sentence, beginning "Whether a lease is intended as security," was not added until the UCC Editorial Board published its 1956 recommendations. See 1956 RECOMMENDATIONS 1-201(37).

55. After the specific langnage of former sections 7-304 and 7-403 concerning consignments and leases, respectively, was dropped in October, 1949, the comment to new section 8-102 indicated that the draftsmen believed the message of the defunct provisions was to be carried by the first two sentences of present section 1-201(37).

56. See pp. 936-42 infra.

57. See note 32 supra and accompanying text.

58. See notes 14-21 supra and accompanying text. 
should be read before the second, the second sentence should be read before the sixth, and the initial clause of the sixth sentence should be read before we read the (a) and (b) clauses of that sixth sentence.

Unlike the fifth sentence which deals with both leases and consignments, the sixth sentence of section 1-201(37) deals only with leases. The initial clause of the sixth sentence states that whether a lease is intended as security is to be determined by "the facts of each case." Unfortunately, and uncharacteristically, the Code leaves the reader unenlightened as to what facts or what principles are significant. Perhaps in recognition of this shortcoming, the comments to section 1-201(37) play down these last two sentences by stating that these sentences "offer guidance" in determining whether a transaction in the form of a lease or a consignment is in actuality a conditional sale. But this guidance apphies only to two out of many sets of facts. ${ }^{59}$ On the other hand, the sixth sentence does at least limit the relevant facts to those bearing on the intent of the parties.

Recalling, then, the counsel of Professor Gilmore that the key to unlock the shorthand cipher of the Code is pre-Code law, one naturally turns to pre-Code law in order to determine what facts are significant in ascertaining whether the parties intended a transaction to create a security interest. Most certainly article 9 directs one first to its lineal ancestor-the Uniform Conditional Sales Act. ${ }^{60}$ Our first question,

59. Other situations in which a nominal lease might be determined to be a conditional sale have been suggested by the Accounting Principles Board:

a. The property was acquired by the lessor to meet the special needs of the lessee and will probably be usable only for that purpose and only by the lessee.

b. The term of the lease corresponds substantially to the estimated useful life of the property, and the lessee is obligated to pay costs such as taxes, insurance, and maintenance, which are usually considered incidental to ownership.

c. The lessee has guaranteed the obligations of the lessor with respect to the property leased.

d. The lessee has treated the lease as a purchase for tax purposes. Accounting Principles Board Opinion No. 5, 2 CCH Accounting PrINCIPLES 6523 (1964).

Clause (a) may be justified on the basis that if the property is useful only to the lessee (for example, a pump placed so far down a well that recovery is uneconomical), the lessee has the full economic life. In this situation, the lessee has presumably obligated hinself to pay at least the purchase price of the item. The second half of clause (b) should be irrelevant for purposes of security law-net leases have been common for decades. Clauses (c) and (d) may be material for accounting treatment but have no great relevance for an article 9 determination.

60. The UCSA was promulgated in 1922 under the auspices of the National Conference of Commissioners on Uniform State Laws, one of the sponsors of the Uniform Commercial Code. Section 1(2) of the UCSA codified long-established law. See generally 3 JONES $\$ \S 952-76$. For discussions of the UCSA as it relates to consignments and leases, see pp. 936-41 infra. 
according to pre-Code authorities and the first sentence of 1-201(37), would be whether there is an obligation to be secured. Pre-Code conditional sales law indicates that the second question would be whether that obligation is to pay an amount substantially equal to the purchase price of the property in which a security interst is asserted. ${ }^{01}$ This message is carried also by the definition of a "sale" in section 2-106 (1): "A sale consists of the passing of title from the seller to the buyer for a price." Viewed against this background, the pre-Code authorities are decidedly correct when they state that if the facts of a transaction include the presence of the usual right of a consignee to return consigned goods, or if a lease contains an option in the lessee to terminate, then there is no obligation to pay an amount substantially equal to the purchase price and thus no conditional sale under pre-Code law as well as no security interest under the UCC. ${ }^{62}$

The view that the lessee's right to terminate contradicts the existence of a full-fledged conditional sale or security interest is consistent with the langnage of section 1-201(37). As was previously pointed out $^{03}$ the second sentence of the section states only that a seller's retained title is limited to a security interest-not that retention of title necessarily creates a security interest. In a "sale or return" or a "sale on approval," a seller retains title in a transaction without creating a security interest; for exainple, the buyer inay have no obligation to pay an amount substantially equal to the purchase price but inay be able to return the goods. In a lease, if an option to terminate exists, a security interest would not be created because the lessee holding the option would be under no binding obligation. And, when interpreted in the light of pre-Code conditional sales law, the first sentence of section 1-201(37) requires such an obligation in order to create a security interest.

If we read the sixth sentence of section 1-201(37) in the order in which it is written and if we find under the introductory clause of the sixth sentence an essential fact which would counterbalance any op-

61. For text of UCSA $\$ 1(2)$, see p. 937 infra. For commentary on the need to obligate the lessee to pay an amount substantially equal to the value of the goods, see pp. 924-27 supra.

62. See Da Rocha v. Macomber, 330 Mass. 611, 116 N.E.2d 139 (1953) (option to purchase but lessee terminates). The necessity for the existence of an obligation to support a security interest is the central theme of this Article. A lessee's power to terminate a lease eliminates the obligation necessary to create a security interest. While this idea is best codified in section 1 of the UCSA, the idea is much older. See 2 S. WILLISTON, supra note $19, \S 226$, at 299 , $\$ 338$, at $307-08$; WhLISTON $\S$ 336 , at $528, \S 338$, at 35 .

63. See pp. 927-30 supra. 
tion to purchase even at a nominal price (such as a right in the buyer to terminate), clause (b) does not need to be read since the issue will have been disposed of by the first clause. ${ }^{64}$ But by first reading clause (b) and declaring an instrument to be a conditional sale any time an option to purchase at a nominal price appears, all such significant facts would be ignored, thereby leading to obviously erroneous results. This conclusion can be easily deinonstrated by an attempt to apply to such cases the remedy provisions of article 9 . If a security interest existed, under section 9-506 the lessee could redeem the collateral upon payment of his "obligation," which is often only a fraction of the purchase price. ${ }^{65}$ The sole argument against this natural reading of the sixth sentenceas opposed to reading clause (b) first and then the rest of the sixth sentence, as was done in the Royer's case-is the use of the little word "however," a conjunction whicll would seem to imply that the clauses following it control the more general preceding language rather than serve as examples of facts which do or do not create a lease intended as security. But to give that word a meaning which would indicate that the Code sponsors had intended to reverse an estabhshed body of preCode law, without their ever even commenting on having done so, is to ascribe to section 1-201(37) a degree of care in drafting which its history does not support. As noted earlier, ${ }^{66}$ when the draftsmen of the section intended to change pre-Code law by declaring that the interest of a buyer of accounts or chattel paper was a security interest, they did it in unmistakable language. The use of the single word "however" in the sixth sentence to change pre-Code law would not be consistent with the drafters' prior style and technique for changing pre-Code law. Such a change in pre-Code law, particularly a uniform statute sponsored by one of the UCC sponsors, would surely have merited at least a coinment. Indeed, such a departure would have required as to leases a counterpart to sections 9-502(2) and 9-504(2) which reeognize that denominating something a "security interest" where the requisite obligation does not logically exist demands a change in remedies as to such artificial "security interests." For example, a lessee who could cancel a two-year lease upon payment of rent already accrued would hardly deserve to "redeem" the leased article upon payment of such accrued rent, as would be the case with a standard security inter-

64. The issue could likewise have been disposed of under the second sentence as interpreted in light of pre-Code law, on the ground that the nonexistence of the required obligation ineans that there is no conditional sale. See pp. 927-30 supra.

65. Under 9-506, the lessee in the Royer's case could have redeemed goods worth over $\$ 4,600$ by paying one month's rent of $\$ 146$.

66. See p. 930 supra. 
est. Furthermore, the change in pre-Code law inherent in this reverse reading of the clauses of the sixth sentence would require some change in section 9-506 and perhaps other sections. Therefore, the sixth sentence should be given a natural interpretation by being read in the order in which it is written.

\section{A PAge OF History}

An understanding of those provisions of section 1-201(37) dealing with leases and consignments for security is dependent upon history. It is a mistake to assume that these problems or their solutions are creations of the Code. While undoubtedly it is true that the volume of dollars involved in leasing has greatly increased since World War II and that leases have become more complex, a great number of the leases which have been litigated under the UCC have been of the garden variety, and very few of the more sophisticated forms of leasing have led to litigation under article 9. The problems encountered today are largely those which existed under the UCSA.

It is probable that the law dealing with what the Code calls consignments for security and leases for security was changed by adoption of the Code only in those states not theretofore requiring filing or recording under the statutory or common law governing conditional sales. On the other hand, the law governing true consignments was changed in many states by Code section 2-236, which, in adopting the position taken by a mimority of states, requires that some form of public notice be made available to the consignee's creditors for assurance that the consignor would be protected against them. However, other than these few basic changes in the pre-Code law, it is important to realize that the problein of when a lease or a consignment is a security arrangement as opposed to an outright sale has long been recognized.

First, the historical development of the law of leases should be examined. We might start with a case that arose just a hittle more than a century ago, Hervey v. Rhode Island Locomotive Works. ${ }^{67}$ On August 21, 1871, Rhode Island Locomotive Works entered into a contract under which it leased to an Illinois railroad one loconnotive engine. The total "rent" was $\$ 12,093.96$, payable by cash payment of $\$ 1,150$ with the balance due in three approximately equal notes, the last of which matured one year from the date of sale. The agreement provided that if the railroad paid the rent in accordance with the terms of the lease, the title shall ipso facto vest in the lessee. Several months later

67. 93 U.S. 664 (1876). 
the sheriff seized and sold the property on behalf of an attaching creditor of the user. The Court said: "It is true the instrument of conveyance purports to be a lease, and the sums stipulated to be paid are for rent; but this form was used to cover the real transaction ....."68 The Court held the reservation of title invalid against the lessee's creditors for failure to comply with applicable Illinois recording statutes which would not have applied had the transaction been a true lease. ${ }^{69}$ In the cases which followed Rhode Island Locomotive Works, soinetimes title passed upon payment of $\$ 1$, or $\$ 10$, or other nominal consideration. In such cases the courts had no trouble in finding a chattel mortgage or conditional sale. ${ }^{70}$ When the option price approaclied the value of the goods at the time the option was exercised, lowever, the courts' reasoning necessarily differed. ${ }^{71}$

Substance continued to prevail over form with respect to purported consignments as well as leases. ${ }^{72}$ In pre-Code days, just as at present, neither the lessee nor the consignee as such was required to make payinent of the purchase price. The consignee was so required only if lie disposed of the goods as agent of the consignor; and the rent payments of a lessee ordimarily were not directly associated with payment of an amount "substantially equivalent to the value of the goods."73 But if there was an obligation to pay an amount roughly equivalent to the value of the goods, and if the obligor upon payment became the owner, the rules changed. When the Uniform Conditional Sales Act was promulgated in 1923, most of the pre-UCSA law was codified in section 1(2):

\section{$\S 1$. Definition of terms.-}

In this Act "Conditional sale" means (1) any contract for the sale of goods under which possession is delivered to the buyer and the property in the goods is to vest in the buyer at a subsequent time upon the payment of part of all of the price, or upon the performance of any other condition or the happening of any contingency; or (2) any contract for the bailments or leasing of goods by which the bailee or lessee contracts to pay as compensation a sum substantially equivalent to the value of the goods, and by which it is agreed that the bailee or lessee is bound to become, or has the option

\section{Id. at 673.}

69. Id. at 672 .

70. For a discussion of cases in this category, see 3 JONES $\S \S 934-68$.

71. See id.

72. The law was already fairly well established in 1909, when Professor Williston summarized the law as to leases and consignments. See WILLISTON $\$ \S 336,338$.

73. UCSA \& 1(2). 
of becoming the owner of such goods upon full compliance with the terms of the contract. (Emphasis added.)

It is important to note the combination of the two key requirements under section 1(2): if the arrangeinent, however called, results in (a) an obligation on the part of the consignee or the lessee to pay an amount substantially equal to the value of the goods and (b) a provision that thereupon the consignee or the lessee becomes or has the option of becoming the owner, the transaction was a conditional sale under the UCSA.

The history of the Uniform Commercial Code begins with the May, 1949 draft of what was then article 7, shortly to become article 8, and ultimately article 9 . This article 7 consisted of seven parts, each of which dealt fairly completely with a type of financing. Part 2 , for instance, dealt with pledges; part 3, with inventory and accounts receivable financing; and part 4, with equipinent liens. ${ }^{74}$ Since consignments are basically related to inventory and leases are associated with equipinent, section 1(2) of the UCSA was divided into section 7-304 with respect to consignments and section 7-403 with respect to leases. Section 7-304(2) described what the Code now calls "consignment for security" in the following words:

If the effect of a consignment is to require the consignee to pay all or a major part of the price of the goods consigned whether or not he disposes of such goods, the consignment is deemed an inventory lien [a security interest] and is subject to this Part in all respects. ${ }^{75}$

There could not be a clearer statement of pre-Code law. And there is no reason to think that it is not also a statement of Code law.

Leases were covered in section 7-403:

When the owner of equipment allows it to be used and controlled in another person's busimess, such arrangement creates an equipment lien if

(a) on the happening of any contingency, title to the equipment is to pass from the owner to the person using and controlling it; or

(b) the arrangement extends or can at the option of the original owner be extended for substantially the expected useful life of the equipment, even though title to the equipment is not to pass to the person using and controlling it in any event. ${ }^{70}$

What is missing from section 7-403 is the first part of the requirement of UCSA section 1(2)-the requirement that the lessee pay an amount

74. MaY, 1949 DrafT art. 7.

75. MAY, 1949 DRAFT $\$ 7-304(2)$.

76. Id. § 7-403. 
substantially equal to the value of the item secured. Also, the comments to this section point out the possible extension of pre-Code law brought about by subsection (b). The draftsmen were seemingly uncertain whether title had to pass under the UCSA for a conditional sale to occur, and they sought to insure the inclusion of transactions where the lessor has the option to require that lease payments be continued for the full useful life of the item. Actually, such transactions could reasonably be included under both the present Code and the UCSA as being just another means by which the lessee effectively "becoines the owner," regardless of whether title passes. While the draftsinen were careful to note in the cominents what they thought might be a relatively minor deviation froin the UCSA, they were strangely silent as to the omission in section 7-403 of the basic UCSA criteria stressed in section 7-304(2): for a conditional sale to occur, the "lessee" must undertake to "pay all or a major part of the price of the goods . . . ." It is impossible to think that this omission was imtentional im light of the draftsmen's habit of commenting extensively on any deviations from the UCSA. ${ }^{77}$ The draftsmen, schooled in pre-Code conditional sales law, must have thought they were carrying over that law in its entirety. Perhaps they thought it self-evident that the owner would not transfer title without such a payment.

Only a few months after the May, 1949 draft appeared, this scheine of separate parts for different kinds of financing was dropped; and the rules of the different parts merged into what became the October, 1949 draft of article 8, the immediate predecessor of article 9. The separate treatments of the lease and the consignment were dropped in the process. The "inventory lien" of part 3, the "equipment lien"

77. Almost a quarter century after the May, 1949 draft of what later became article 9 , it is not apparent why the draftsmen failed to make it clear that they were carrying forward the UCSA's provisions governing the treatment of certain leases as conditional sales. The comments to old section 7-304, dealing with consigninents for security, almost exphcitly restated the pre-Code law. But when the draftsmen came to the coinparable problem of when a lease becomes a conditional sale, the same draftsmen apparently were content to rest upon what is now the first sentence of section 1-201(37) (then contained in both 1-201(30) and the definition section of old article 7). The significant point is that the draftsinen, particularly at this early stage, noted all deviations from the Uniform Laws endorsed by a sponsor of the Code-the National Conference of Commissioners on Uniform Laws. The draftsmen were meticulous in expressing doubts as to whether they had extended that law in section 7-304(b)-doubts which were real, but only doubts. It is inconceivable that they likewise would not have commented on changes in the heart of the UCSA's provisions on leases for security. The draftsmen, steeped as they were in pre-Code chattel security law, apparently considered this doctrine to be so well accepted as the law that the umbrella of the first sentence was sufficient, with no need for specification. 
of part 4, and the pledge of part 1 were all absorbed into the colorless "security interest." No intention to depart from earlier law is indicated by the October, 1949 draft of comment 1 to section 8-102, the immediate predecessor of section 9-102, which defines the scope of the article. The comment contains this sentence:

Transactions in the form of consignments or leases may be security transactions if the understanding of the parties or the effect of the arrangement is to show that the manifest intent was to create a security interest (defined in Section 1-201(30)). ${ }^{78}$

In the October, $1949 \mathrm{draft}$, the forerunner of present section 1-201 (37) read essentially as the first and second sentences of 1-201(37) now read, except that the basic concept that retention of title is "limited to a security interest" was applied to a consignor as well as to a seller, ${ }^{70}$ whereas only sellers are included under the second sentence of the present section 1-201(37).

Due to this deviation from pre-Code law incorporated in previous drafts and the confusion thereby created, the fifth sentence of section 1-201(37) was added to clarify the situation. The language of section 1-201(37) (later dropped) with respect to the title retention by a con. signor, though probably teclımically correct, was confusing. ${ }^{80}$ "True"

78. October, 1949 DRAFT $\$ 8-102$, Comment 1. Section 1-201(30) of the May, 1949 UCC draft was the predecessor of present section 1-201(37).

79. From an earlier day, the Code provided that not every retention of title is a security interest and that no retention of title is more than a security interest. In early drafts, other parts of the UCC, particularly section 2-326, gave more details as to certain title retentions. Later-abandoned section 7-304 distinguished between the retention by a consignor who had agreed to pay the purchase price whether or not he disposed of the goods (a full-fledged security interest) and the ordinary consignment, which is subject to and only to the public notice provisions of 2-326. With regard to protection of title retention against the deliveree's creditors, this section also distinguished between a seller whose sale was a "sale or return" and one whose sale was "on approval." The title retained by a seller in a "sale or return" could be protected only by coinpliance with subsection 2-326(3), while the title retained by a seller in a "sale on approval" required no comparable action. By its silence, the Code did not inake the property interest retained by a lessor subject to the claims of the lessee's creditors.

80. As late as 1952, section 1-201(37) stated that title retention by a seller or consignor is limited to a security interest. See 1952 OfFICIAL DRAFT $\$ 1-201(37)$. To one who reads as he runs, this might have created an implication that all title retentions of a consignor were security interests-an interpretation which was completely negatived by abandoned section 7-304. That section made it crystal clear that only consignments in which the consignee agreed to pay the purchase price were security interests, but this clarification was expunged along with section 7-304. The statement was not necessarily wrong-by subjecting the consignor's title retention to claims of the deliveree's creditors unless the consignor complied with 2-326, the Code did indicate that the consiguor's title retention was something less than, say, the title retention of the lessor, whose interest the deliveree's creditors could not attach. 
consignments and "true" leases have never created security interests, and the mere inclusion in a lease of an option without more has never created a security interest. The wording of the phrase "upon the happening of any contingency" in UCSA section 1(1) appeared in looser form in section 7-402 of the UCC and conceivably could have been read as making any passage of title, even upon payment of the market price of the goods, into a security interest. This change from the language of the UCSA might have been interpreted as reversing that well established law. The fifth sentence of section 1-201(37) was written to negate these possible misinterpretations as to both consignments and lcases. The inclusion of clause (a) of the sixth sentence can be explained for the same reason. Clause (b) of that same sentence probably was intended specifically to save the substance of section 1(2) of the UCSA.

Probably the acts which have caused the inost confusion were the deletions of section 7-304 on consignments and the comments to section 8-102, each of which made it clear that the draftsinen based their treatment of consignments and leases on the UCSA. These omissions only can be ascribed to pure inadvertence. When the decision was inade to abolish the separate parts of article 7 and to merge the separate definitions of the different individual kinds of security interests into the all-inclusive term "security interest" of section 1-201 (37), the problein passed primarily from the control of the draftsmen and advisors on secured transactions to the draftsmen and advisors on the Code's general provisions, including definitions. Coordination was less than perfect. Partly as a result of this shift, the inore explicit language of old articles 7 and 8 and their valuable references to the UCSA were lost in the shuffle.

\section{Conclusion}

Section 1-201(37) should be read forwards, and not backwards. The first sentence of that section states that two essential elements must exist in order that a security interest be found: (a) a property interest and (b) an obligation which that interest can secure. If both of these elements are found to exist, the second sentence requires that a determination be made as to whether the transaction involved is a conditional sale. If the deliveree is under no obligation to pay an amount substantially equal to the purcliase price, the answer of pre-Code law is that the transaction is not a sale. It could be a lease, a consignment, or some other form of bailment-or even a gift.

With the foregoing overview of section 1-201(37) as groundwork 
it is now possible to explore further the separable problems therein. The lease, the consignment, the sale of accounts and chattel paper, and the acquisition by a buyer of a special property in goods not yet delivered are commercial devices each of which may or may not create security interests which meet the tests of the first sentence of 1-201(37). Yet, as we have seen in the foregoing analysis of 1-201(37) and 9-102, the Code treats each of these devices in a different fashion, with little explanation of the rationale behind these variations. As we treat each separately, we may question whether and why a particular treatment is appropriate.

\section{Rights of BuYers of AcCounts and Chattel PAPER As SeCurity INTERESTS}

As noted ${ }^{81}$ the third sentence of section 1-201(37) includes in the definition of a security interest "any interest of a buyer of accounts or chattel paper ...." Yet, since in an outright sale of accounts or chattel paper there is neither an obligation on the part of the seller nor any property interest remaining in him to secure the obligation, there can be no "interest in personal property or fixtures which secures payment or performance of an obligation" as required by the first sentence of section 1-201(37). Therefore, the question naturally arises as to why almost all sales of accounts are included in article 9.82 It is reasonable to ask whether this treatment is sensible and appropriate. Clearly, the practical difficulty of differentiating between a true sale, as opposed to an assignment for security, must be considered when eval-

81. See p. 930 supra. Prior to the 1972 amendments, both 9-102 and 1-201(37) also referred to sales of "contract rights," a term merged in 1972 into the definitions of accounts and general intangibles. To avoid some serious problems with respect to some general intangibles which are not rights to payinent of money, a sale of general intangibles is not a security interest even though some general intangibles are economically indistinguishable from accounts. A debtor may sell his right to receive money froin (a) the sale of goods, (b) the rendering of services, and (c) the sale of a patent. Because the definition of accounts limits its coverage to rights arising out of the sale of goods or the rendering of services, however, the sale of the right under clause (c) is not a security interest. By contrast, a borrowing secured by the right to proceeds from the sale of a patent as collateral would be a security interest. For a discussion of some problems encountered in the Code's treatinent of sales as security interests, see Coogan, Kripke, \& Weiss, Outer Fringe of Article 9: Subordination Agreements, Security Interests in Money and Deposits, Negative Pledge Clanses, and Participation Agreements, 79 HARV. L. REv. 229 (1965), reprinted with changes in P. Coogan, W. Hogan, \& D. Vagts, Secured Transactions Under the Uniform COMMERCIAL CODE ch. 23 (1963-73).

82. Section 9-104(f) excludes from all provisions of article 9 certain sales of accounts, and 9-302(1) (e) excludes from its filing provisions certain assignments. Neither section is likely to be particularly significant. 
uating the decision of the Code draftsmen to define all sales of accounts and chattel paper as security interests. These judgments are best made after examining the actual effect and applicability of the pertinent provisions of article 9 as applied to the sale of accounts and chattel paper. But, first, we briefly examine the business reasons for negotiating a sale of accounts instead of a borrowing secured by accounts.

A purchase of accounts may be preferred over a loan secured by accounts essentially for credit reasons. A financer may prefer to buy accounts if he anticipates more than the most remote possibility that the debtor will become bankrupt or become involved in a reorganization. Actually purchasing the accounts, rather than taking a security interest in them, may avoid possible delay in collecting on the accounts if the trustee in reorganization should find it necessary to use proceeds which are subject only to a security interest and in which the debtor could be said to have an equity. ${ }^{83}$

There are also many cases where a sale of accounts or chattel paper is made for noncredit purposes. There may be a tax advantage im selling long-term installment accounts at a particular time. ${ }^{84}$ Also, in certain industries, factors or other financers have developed credit investigation and collection processes which enable the account seller to realize a greater net return on his accounts by selling them than he could obtain after performing these services himself and paying the mcidental costs. Another possible reason for a sale is that the owner of accounts may desire to obtain cash with a minimum decline in his asset-to-debt ratios. A sale of accounts may permit this result because it involves the exchange of one type of asset (accounts) for another (cash), rather than the imcrease in debt which offsets the acquisition of cash im a borrowing. ${ }^{85}$

83. Reconstruction Fin. Corp. v. Kaplan, 185 F.2d 791 (1st Cir. 1950), is often cited for the proposition that the trustee in reorganization can be given a right to use, in the debtor's business, proceeds of accounts held by the secured party because the debtor could be said to have an "equity" in these proceeds. Where accounts have been sold with no accountability to the seller for any surplus over the purchase price, the debtor has no such equity.

84. In East Coast Equip. Co. v. Commissioner, 222 F.2d 676 (3d Cir. 1955), the court held that an assignment of installment paper was, for tax purposes, a sale rather than a pledge, notwithstanding a guaranty of payment of the paper by the transferor. The Third Circuit explained that such a guaranty was no different from a warranty accompanying a sale of a chattel. Id. at 677.

85. A seller of accounts will usually receive less than the full face value of the accounts; thus a shight decline in his asset-to-debt ratio will usually follow an outright sale of accounts. However, where the seller's initial asset-to-debt ratio is greater than unity, and especially in situations where the initial ratio is relatively high, the decline in that ratio following an outright sale of accounts would alinost certainly be less 
Even though there may be sales of accounts or chattel paper which have no security characteristics, the Code arbitrarily seems to make the interest of the buyer a security interest. In fact, since the Code necessarily recognizes that true sales are not subject to at least some of article 9's remedy provisions, ${ }^{86}$ it would be more accurate to say that the Code makes all such sales subject to its public notice, ${ }^{87}$ priority, ${ }^{88}$ and statute of frauds provisions. ${ }^{89}$ On the other hand, certain article 9 reinedies, otherwise automatically applicable, apply only if the parties so agree. ${ }^{00}$ This treatment of accounts and chattel paper is not without good reason. Public policy dictates the necessity of complying with at least the public notice and priority provisions to assure the protection of creditors. With the sale of accounts or chattel paper, the debtor's most liquid assets (excluding cash) are reinoved froin the pool of assets to whicli a creditor may look for payment when a debtor defaults. Creditors may justly feel that the same kind of public notice should be given to them with a sale of accounts as with a borrowing against accounts which creates a standard article 9 security interest. Without such notice the creditor may extend credit under the mistaken assumption that there is adequate unencuinbered collateral available to insure the paysnent of the debt. Further, the priority rules of article 9, including the first-to-file rule of section 9-312(5) (a), might work poorly if sales of accounts were outside the scope of the article. By meeting all the requirements established for perfection of a security interest in accounts, the purchaser of accounts is protected from claims by holders of unperfected security interests, while other parties are protected agamst that purchaser in accordance with article 9's priority rules. Also, the seller of accounts or chattel paper may execute an article 9 security agreement in order to satisfy the statute of frauds provision of section 9-203(1)(b). By searching the filing records and

than that which would result from the equal debiting of assets and crediting of liabilities that accompany a borrowing of funds.

86. See, e.g., UCC $\$ \$ 9-502(2),-504(2)$.

87. Id. $\S 9-302(1)$, providing in part that a "financing statement must be filed to perfect all security interests" not specifically excepted by 9-302. However, under sections 9-304 and 9-305, a security interest in chattel paper can be perfected, sometimes with superior priorities, by the secured party's possession. See note 88 infra. For possible complications, see id. $\$ \$ 9-306,-308$ to -309 .

88. Id. $\S \S 9-312(5)$ to (7), -304 to $-306,-308$ to -309 (chattel paper).

89. Id. $\S 9-203(1)$ (a). A signature of the debtor-assignor is required for every security agreement concerning accounts, except that this requisite is excused for isolated, insubstantial transactions under section 9-302(1)(e). If chattel paper is delivered to or on behalf of the secured party, no writing or filing is required. Id. S§ 9203 (1)(a), $-302(1)(\mathrm{a}),-305$.

90. See, e.g., id. \$\$ 9-502(2), $-504(2)$. 
complying with the mechanics of filing, the purchaser can be assured of protection against holders of all unfiled interests and against those who later become lien creditors of or purchasers from the debtor. By this procedure the relative rights of all parties with interests in the debtor-seller's accounts are established and protected. Procedures as to chattel paper are somewhat more complicated because of the possibility of a perfection either through possession or filing; but since chattel paper transactions, like accounts transactions, are handled by professionals, the complications of sections 9-304, 9-305, 9-306, and 9-309 can be taken in their stride.

However, as intimated above, some of the standard remedy provisions of article 9-the inost vital sections for the secured creditor-do not apply to the true sale of accounts or chattel paper unless the parties expressly so agree. Whether one can properly call the interest of the buyer a true security interest is a matter of word usage. Convenience is its justification. In a full-fledged security transaction, the enforcement machinery of article 9 normally provides procedures by which the secured party, upon the debtor's default on his obligation to pay, can repossess and sell the collateral and pay himself out of the proceeds. The secured party is able to realize on his collateral only in accordance with the rules of part 5 of article 9, which are designed to protect whatever equity the debtor may have in the collateral; and, on the other hand, the debtor is liable to the secured party for any deficiency between the amount of the debt secured and its proceeds. These respective remedies of the secured party and the debtor apply automatically, without express agreenent. In fact, where the debtor promises, im advance of a default, to waive his equity, such an agreement would be unenforceable under section 9-501.91 These rules are the heart of a full-fledged security imterest, one in which there is an indebtedness to be secured. But a "sale" by the account buyer of his "debtor's" (the account seller's) nonexistent interest in the accounts would be meaningless. As a result, sections 9-502(2) and 9-504(2) treat differently an outright sale of accounts or chattel paper and an assignment of these interests as security for a borrowing. ${ }^{92}$ Fully rec-

91. Sections 9-501 through 9-506 prescribe these default rules. Section 9-501(3) allows the debtor to waive or vary its part 5 rights only in certain circumstances, which do not include section 9-506, at least if the agreement was made before default.

92. There is no precedent for this treatment in the pre-Code statutes with assignments of accounts receivable, for these acts dealt primarily with the imposition of an excuse from filing requirements for validation of assignments and practically never encompassed remedies of the parties. Consequently, these statutes did not face the question at least partly handled by section 9-502. See generally 1 GILMORE $\$ \cdot 8.7$, at 274. 
ognizing that a sale and an assignment for security could not be handled in the same manner under the remedy provisions, the draftsmen of article 9 provided in 9-502(2) and 9-504(2) that:

[i]f the security agreenent secures an indebtedness, the secured party must account to the debtor for any surplus, and unless otherwise agreed, the debtor is liable for any deficiency. But, if the underlying transaction was a sale of accounts or chattel paper, the debtor is cntitled to any surplus or is liable for any deficiency only if the security agreement so provides..$^{93}$

But the language of section 9-502(2) bears close scrutiny. It does not say that in a true sale of accounts the "debtor" (the account seller) cannot incur an obligation to pay any deficiency that the secured party (the account buyer) might suffer when he ultimately collects on the accounts, nor does the provision say that the buyer cannot agree to pay over any proceeds in excess of the purchase price. It says that unless there is explicit agreement to that effect, there is no such obligation to pay a deficiency and no such right to a surplus. The thrust of section 9-502(a) is the reverse of the usual ruling in a full-fledged security agreement-namely, that the debtor is obligated to pay the deficiency unless the secured party agrees otherwise.

What distinguishes a sale of accounts or chattel paper froin a borrowing for which they furnish security? Casting the transaction in the form of a sale is not difficult when the parties agree upon a price which adequately reflects the value of the accounts, a discount for bad debts, and the interest costs froin the time of the sale until all accounts are collected. But where the seller thinks the price offered is too low, he may request that le receive additional payments if the accounts pay out as he predicts. Or the buyer may insist upon the deficiency payinents by the seller if collection of the accounts does not meet expectations. There also may be reserves, loldbacks, and warranties. As the complications multiply and as the risks traditionally shouldered by the respective parties to a sale are shifted by agreement, the transaction may take on more of the effects of a borrowing secured by accounts. Since the Code requires that the distinction between a sale and a secured borrowing be drawn only when someone-usually one of the parties-raises the issue at the time of enforcement and since each such case will present its own peculiar facts, it is clear that the Code draftsmen consciously chose not to prescribe standards for this distinction. ${ }^{94}$

93. UCC \& 9-502(2). Section 9-504(2) differs from this provision only with respect to the substitution of the phrase "security interest" for "security agreement" at the beginning of the passage.

94. Sée UCC $\$ 9.502$, comment 4. 
Instead, they chose simply to make all transactions involving accounts and chattel paper subject to the public notice, priority, and statute of frauds provisions of article 9, thereby lessening the adverse impact in the event that what at least one of the parties thought was a sale is later held by a court to be an assignment for security. If a secured party who has complied with the Code's provisions for accounts or chattel paper ends up with a secured borrowing instead of the sale he thought he had, his only loss to the debtor or to some third party is likely to be a claim to proceeds in excess of his purchase priceloan. If, on the other hand, general compliance with article 9 had not been required and the secured party had not complied voluntarily, such a presumed "buyer" of accounts or chattel paper would have found himself the holder of an unperfected security interest-in effect, in most cases, an unsecured creditor. While the Code's arbitrary creation of security interests in a nonsecurity transaction has not been without its problems, ${ }^{95}$ on balance, it is probably as good as any other treatment might have been.

In summary, it should be noted that any inconvenience caused by article 9's requirement of compliance with its filing, priority, and statute of frauds provisions is more than offset by the protection afforded the parties and nonparties. As a result of this rule, the difficult analysis of whether the transaction is a sale or an assignment need not be made at the outset. The "secured party," be he a buyer or a lender, is told that unless he complies with the Code's mandates, his interest is vulnerable to attack by a creditor of the assignor, including the assignor's trustee in bankruptcy or a purchaser of the accounts, regardless of the nature of the transaction. There is no decision as to whether to comply; the Code specifically makes compliance mandatory for all transactions involving accounts and chattel paper. With this understanding of the Code's method of handling accounts and chattel paper, we can consider whether this model used by the Code's draftsmen would be appropriate for consignments and leases.

\section{The Code's Treatment of Consignments}

The UCC approach to consignments illustrates another option not adopted by the Code's draftsmen in the commercially important area of leases. Section 1-201(37) provides that the consignor's retention of title is not a security interest unless the consignment is intended for security, but that every consignment is subject to the provisions of sec-

95. See Coogan, Kripke, \& Weiss, supta note 81. 
tion 2-326 in the sales article. ${ }^{96}$ We have reviewed the history of 1-201(37) and the now-abandoned 7-304 on the first point.97 However, we have not adequately studied the relationship of section 1-201 (37) to section 2-326, nor have we explored new section 9-114, added as part of the 1972 amendments.

Section 1-201(37) inandates coinpliance with $2-326,{ }^{98}$ regardless of whether a consignment is one for security. ${ }^{09}$ Reversing the preCode law in most jurisdictions, ${ }^{100}$ section 2-326 requires that a consignor give sufficient notice to the consignee's creditors that not all goods in the consignee's possession are his own; noncompliance with this section allows the creditors of the consignee to treat the consignor's goods as those of the consignee in any subsequent default proceedings. ${ }^{101}$

96. See notes 103-105 infra and accompanying text.

97. See pp. 936-42 supra.

98. The reader should not be misled by the term "consignment sales" as used in section 2-326. A consignment is not a sale, nor is a sale a consigninent. Rather than selling his goods to a consignee, a consignor merely delivers goods to the consignee with a power to sell on behalf of the consignor. If the consignee does sell the goods, he has a duty to remit the proceeds of the sale, less his previously established commission. The consignor must insist upon keeping his goods identified; and since a consignee might be tempted to increase his commissions by selling a large volume of someone else's goods at a great bargain, the consignor regularly sets the sale price.

99. The scheme of section $2-326$ is indirect. Subsection (1)(a) defines goods on "sale or approval" as goods delivered "primarily for use," and (1)(b) defines goods on "sale or return" as goods "primarily for resale." Subsection (2) then recites that goods on approval are not subject to claims by the buyer's creditors while in the buyer's possession, but that "sale or return goods" are subject to such claims. Since a consignment is not a sale, neither (1)(a) nor (1)(b) directly applies. Then, however, subsection (3) provides that

[w] here goods are delivered to a person for sale and such person maintains a place of business at which he deals in goods of the kind involved, under a name other than the name of the person making delivery, then with respect to claims of creditors of the [consignee] the goods are deemed to be on sale or return [and thus subject under subsection (2) to claims of the consignee's creditors].

Bnt these goods are not to be so "deemed," and hence not subject to the consignee's creditors, if the consignor complies with the public notice requirements of section 2 . 326(3). See notes 103-05 infra and accompanying text.

100. See Ludvigh v. American Woolen Co., 231 U.S. 522 (1913); Leibowitz v. Voiello, 107 F.2d 914 (2d Cir. 1939).

101. While a true consignment does not fit the pattern for a complete article 9 security interest, it does not necessarily follow that the public notice system of article 9, or some effective substitute, should not be applied. In Leibowitz v. Voiello, 107 F.2d 914, 916 (2d Cir. 1939), Judge Clark raised this very issue, implying that it was difficnlt to understand why some form of public notice should not bo just as necessary in a consignment as in the case of a chattel mortgage. However, the court in Leibowitz was unable to find against the consignor because of the United States Supreine Court's decision in Ludvigh v. American Woolen Co., 231 U.S. 522 (1913), where a consignment was upheld though no notice had been given. A minority of the states 
Goods transferred on a "sale or return" basis-that is, where "goods are delivered primarily for resale" 102 but may be returned-are subject to the claims of the consignee's creditors while in the consignee's possession unless the consignor (1) complies with an applicable "signposting" statute, ${ }^{103}$ (2) estabhishes that the consignee "is generally known by lis creditors to be substantially engaged in selling the goods of others," ${ }^{104}$ or (3) files under article $9 .{ }^{105}$ This rule governs true consignments as well as those executed for security. ${ }^{106}$

The consignment for security-more accurately, the conditional

required some form of public notice, including the posting of signs. See note 97 supra. Section 2-326(3), consequently, reversed the rule of Ludvigh except possibly to the extent that under 2-326(3)(b) formal notice is excused where the consignor can "establish" that the consignee's creditors generally knew the consignee was "substantially engaged in selling the goods of others . . .."

102. UCC $\$ 2-326(1)(b)$.

103. Id. $\S 2-326(3)$ (a). A minority of the states have from time to time established some public notice requirements. Some of these are the "Trader's Acts," or sign-posting statutes, which seem to be traced to a Virginia statute that dates back to 1839. See Act of March 28, 1839, ch. 73, § 2, [1839] Acts of Va. 45. This statute was amended upon the adoption of the UCC. See Act of March 12, 1956, ch. 335, § 1, [1956] Va. Laws 391 (repealed 1973).

Compliance with the Virginia sign-posting statute would appear to be more difficult than coinpliance with article 9's filing requirements. In addition to posting a sign that gives notice of the true owner's interest in the goods, the statute requires a "notice published for two weeks in a newspaper printed in the city." Id. The Virginia act served as a model for legislation in Arizona, Mississippi, North Carolina, and West Virginia. E. Farnsworth \& J. HonNold, CASES AND Materials on COMmercial LAW 749-50 (1965).

Some states have required filing for consignments. See, e.g., Ch. 81, [1937] Wis. Laws 102 (repealed 1963), applied in In re Miske, 159 F. Supp. 677 (E.D. Wis. 1958). A similar statute was interpreted in Hudnall v. Paine, 39 Fla. 67, 21 So. 791 (1897). The Hudnall court remarked that statutes with the same purpose as Florida's then existed in Alabama, Kentucky, Virginia, West Virginia, and probably other states. Id. at 72, 21 So. at 793.

For other "Trader's Acts," see 10 ARIz. REv. STAT. ANN. § 29-101 (1956); 5 Miss. Code ANn. § 15-3-7 (1972); 2C N.C. Gen. Stat. § 66-72 (1965). These states, unlike West Virginia, did not repeal or amend their "Trader's Acts" upon adoption of the UCC. See CoDe OF W. VA. ch. 100, § 13, at 541 (1868) (repealed 1963).

This Article does not concern the effect of these "Trader's Acts" upon UCC transactions.

104. UCC \$ 2-326(3)(b); see, e.g., Guardian Discount Co. v. Settles, 114 Ga. App. 418, 151 S.E.2d 530 (1966); In re Mincow Bag Co., 29 App. Div. 2d 400, 288 N.Y.S.2d 364 (1968), aff'd mem., 24 N.Y.2d 776, 248 N.E.2d 26, 300 N.Y.S.2d 115 (1969).

105. UCC $\$ 2-326(3)(c)$. The filing is a financing statement described in section 9-402 and completed in accordance with part 4 of article 9. The 1972 revisions to article 9 have added section 9-114 to deal specifically with the notice requirements of a person who delivers goods under a consignment which is not a security interest.

106. A consignor who complies with the provisions of article 9 will automatically satisfy section 2-326. 
sale masquerading in consignment form-is, of course, controlled by article 9's filing, statute of frauds, priority, and remedy provisions. In addition, when the new section 9-114 becomes effective, it will subject even true consignments to article 9's notice and priority provisions. Under new section 9-114, im order for a consignor to protect his ownership in goods in the hands of a consignee who creates in favor of another creditor a security interest in inventory of the same type, the consignor not only must complete an article 9 filing under 2-326(3) (c) but also must give notice to holders of security interests covering the inventory of the consignee-debtor before the goods are delivered to the consignee. Thus, although a consignor can protect himself from the consignee's unsecured creditors by methods other than compliance with 2-326(3)(c), the consignor who fails to file and notify under article 9 risks losing priority to another imventory financer who filed earlier.

These changes made by the Code in its treatment of consignments were prompted, in part, by the fact that the consignee's creditors, secured and unsecured, may be misled by his apparent ownership of goods whether subject to a security agreement or a true consignment. Thinking there is adequate collateral to insure payment, a supplier may furnish goods on the strength of a consignee's apparent ownership of consigned goods; and an inventory financer likewise may be deceived into lending on the basis of such goods, unless some form of notice is required for consignments. The fact that there is a burden placed on the consignor is obvious, but it is no more of a burden than that placed on nearly all secured creditors since adoption of the Code, on those who gave security under many statutes governing assignments of accounts receivable, ${ }^{107}$ and on those who, for years in pre-Code history, supplied goods through the Uniform Trust Receipts Act, ${ }^{108}$ the Uniform Conditional Sales Act, and the so-called "factors lien acts."100 If a consignor does not somehow comply with section $2-326$, his goods may be subject to the claims of a hen creditor; if the consignor does not file and give notice under section 9-114, he may lose out to another secured party. ${ }^{110}$

107. Slightly more than half of the states had required filing for assignment of accounts immediately prior to adoption of the UCC.

108. For a discussion of the highly technical but useful trust receipt, see 1 GLLMoRs $\S \S 4.4-9$.

109. Professor Gilmore has discussed the so-called "factors lien acts"-a queer collection of statutes, most of which had a very short life immediately prior to the general adoption of the UCC. See id. \$§ 5.1-.6, 8.6. See note 23 supra.

110. The Code's handling of consignments is fraught with uncertainty, and the score of Code cases on the subject clears up little. Indeed, it is diffi- 
In pre-Code days, and particularly before the Uniform Trust Receipts Act and the so-called "factors lien acts" which made inventory liens feasible, consignments may have been used as a means of providing security of a sort to a supplier of goods. At least the consignor could reclaim his goods. But since a consignee by definition has no obligation to pay for goods unless he sells them, today a consignment is at best a half-hearted security device greatly inferior to an ordinary UCC security interest in inventory. ${ }^{111}$ A perfected security interest is no more difficult to create and gives the supplier the double advantage of recovering his goods if they have not been sold and of recouping from the buyer any deficiency if the subsequent sale by the secured party does not bring an amount sufficient to cover the purchase price of the goods. Therefore, the use of consignments for true security purposes may be expected to be minimal in these days of easily created UCC inventory security interests.

An independent development in the antitrust field has further reduced the usefulness of consignments. For many years following the 1926 decision in United States v. General Electric Co., ${ }^{112}$ consignments were used as a means by which a wholesaler could dictate the price at which his "consignee" sold the goods as agent of the consignor. However, recent decisions in the antitrust field lave blunted the effectiveness of the consignment as a tool for controlling retail sales

cult to explain why consignors have litigated so many cases. In all but one or two the consignor could hardly have expected to prevail since he did not comply with Article Nine and did not comply with 2-326 of Article Two. J. WhITE \& R. SUMMERS, supra note 2, § 22-4, at 765 (footnotes omitted).

The authors cite most of the cases decided by 1972 but fail to mention the wellestablished tests of pre-Code law as to when a consignment is a conditional sale. Without prc-Code law, not only is the "Code's handling of consignments fraught with uncertainty"-it is unintelligible. The Code draftsmen may have assumed that this branch of the law was so well settled that a restatement was unnecessary.

The statement of Professors White and Summers that complance with section 2-326 should constitute compliance with article 9, id. $\$ 22-4$, at 769 , seems to have no justification in the words or the purpose of the Code. One who searches for article 9 security interests cannot be expected to determine whether the debtor and secured party have complied with some local sign-posting statute. And the questions of White and Summers as to what a consignor does on default evidence a misconception of the nature of a consignment. Since the consignee by definition is under no obligagation to pay for goods not sold, where is the default?

111. See id. \$ 22-4, at 765-66.

Now that a consignment agreement, by itself, is no longer sufficient to create a "secret lien," the seller looking for security will much prefer to see the goods subjected to a purchase money security interest as controlled by the UCC's priority provisions in section 9-312. Besides the right of getting the goods back, this security interest also gives the seller a priority in identifiable cash proceeds received on or before the delivery of the inventory to a buyer under certain conditions. UCC \& 9-312(3).

112. 272 U.S. 476 (1926). 
prices on any broad scale. ${ }^{113}$ Nevertheless, because the consignee only obligates himself to return to the consignor either an agreed portion of the retail sales price or the unsold goods, the consignment remains a valuable marketing device which enables the manufacturer or wholesaler to display his goods with retailers and other distributors who are unwilling or unable to obligate themselves for the purchase price. ${ }^{114}$

Furthermore, an advantage of the Code's approach to true consignments may arise from the fact that such transactions were not subjected to article 9's statute of frauds provisions, but instead would seem to be governed by the relatively flexible statute of frauds provisions of article 2.115 Such treatment would seem desirable since the true consignment more closely resembles a sale than a secured transaction. However, since a consignment may be treated as a "sale or return" only if one of the notice provisions of section 2-326(3) is not satisfied, whether article 2's statute of frauds provisions control all true consignments depends upon the extent to which the provisions of article 2 are applied to nonsale transactions. ${ }^{118}$

Nonetheless, the counseling moral in the consignment area is clear - the consignor's only sensible procedure is to file and notify under

113. In United States v. General Elec. Co., 272 U.S. 476 (1926), the Court concluded that the 21,000 retailers who were authorized to sell consigned light bulbs were "genuine agents" of the company and that the company, as principal, could set the sales price of these items. Although conceding that the comprehensiveness of the scheme should bring it under the antitrust law, the Court found that General Electric was only exercising its rights as a patentee to make, use, and sell the patented article.

Later the Suprene Court declined to extend this exception for consigned goods to the arrangement considered in Simpson v. Union Oil Co., 377 U.S. 13 (1964). The plaintiff in this case, a retail gasoline dealer, was attacking a "consignment" agreement which the oil company was using to set the price at which the retailer sold gasoline.

Few antitrust lawyers would encourage clients to rely on the old General Electric case. The antitrust division of the Department of Justice has consistently sought to persuade the Court to overrule General Electric; and in a 1973 case involving the same defendant, the antitrust division persuaded a federal district court in New York to hold that the old doctrine has in effect been abandoned. United States v. General Elec. Co., 358 F. Supp. 731 (S.D.N.Y. 1973).

114. For a general discussion of consignments, see 4A CollIER on BANKRUPTCY, supra note $2, \llbracket 70.18(5)$; R. DUESENBeRg \& L. KING, SALES \& BULK TRANSFers $\$ 11.01$ -

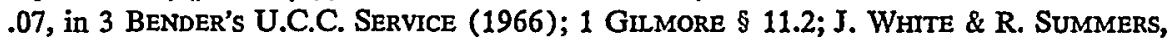
supra note $2, \S 22-4$, at 765 . For a superior treatment of this topic, see Duesenberg, Antitrust Considerations, supra note 2. See also Duesenberg, Emerging Principles, supra note 2 (an astute analysis of Columbia Int'1 Corp. v. Kempler, 46 Wis. 550, 175 N.W.2d $465(1970))$.

115. See UCC \& 2-201.

116. It is beyond the scope of this Article to discuss the applicability of UCC article 2 to lease transactions. 
article $9,{ }^{117}$ smce in any event section 2-326 requires some public notice $^{118}$ and particularly since the new section 9-114 mandates article 9 filing and notification ${ }^{119}$ in order to preserve priority against imventory financers who have filed earlier than the consignor. His two alternatives under subsections 2-326(3)(a) and (b) are less viable options. First, with respect to 2-326(3) (a), most states lack any signposting statute; and compliance with this type of law appears to be at least as difficult as adlicrence to article 9. ${ }^{120}$ Second, the consignor would be ill-advised to rely on his ability to establish under 2-326 (3) (b) that a consignee is generally known to creditors as dealing substantially in goods not his own. Do the Atlanta and Dallas creditors of a Baltimore consignee have this vital information about the Baltimore business?

One looking at the Code's provisions for the first time inay well conclude that every user of the consignment device must decide at the inception of the transaction whether he has a consignment for security, which requires compliance with article 9, or a "true" consignment, which demands no such compliance. ${ }^{121}$ However, if the simple practice of filing and giving notice under article 9 is observed, the necessity of identifying a consignment for security will arise only where a party questions whether the transaction creates a security interest subject to the remedy provisions of part 5 or article 9 . The consignee may assert that the consignor can reclaim his collateral only according to the debtor-protective provisions of part 5 . However, inasmuch as a consignee is unlikely to have any direct or indirect investment in the consigned goods, this possibility is remote unless a significant departure from consignment practice occurs. On the other hand, a consignor may claim that the consignee obligated himself to pay for the goods whetler or not lie sold them, that the arrangement was really for security (a conditional sale), and that the consignor is therefore entitled to a deficiency for the difference between the purchase price and the proceeds of disposition of the collateral.

117. UCC section 9-114 outlines the necessary steps for filing and notification. The deadlines for notification in order to obtain priority among conflicting security interests in the saine collateral are set forth primarily in section 9-312.

118. See notes 103-06 supra and accompanying text.

119. UCC $\$ \S 9-114$ (a) (filing) (b)-(d) (notification). See also id. \$ 9-312(3).

120. This fact may be illustrated by comparing article 9 filing procedures with the mechanics of Virginia's defunct signposting statute, Act of Marcl 12, 1956, ch. 335, \& 1, [1956] Va. Laws 391 (repealed 1973).

121. Once the actual agreement of the parties is determined, its classification as a true consignment or a disguised conditional sale should be an easy question-has the consignee obligated himself to pay the purchase price regardless of whether he sells the goods? 
The result is that while it should not ordinarily be difficult to determine whether a consignment is one for security, i.e., whether the consignee has agreed to pay whether or not the goods are sold, ${ }^{\mathbf{1 2 2}}$ only in rather rare circumstances is it likely to become necessary to make this determination. Similarly, the UCC tactic of treating all transactions in accounts and chattel paper as article 9 security interests directly reduces the need to determine whether such a transaction is a sale or an assignment for security. Since he must give notice somehow (and where section 9-114 is in effect, satisfy article 9's priority provisions), the consignor may as well almost automatically comply in full with article 9. To do so, he need only reduce his agreement to a writing signed by the consignee.

In dealing with leases, however, the draftsmen of the Code did not elect to follow the pattern of postponing or avoiding the question of whether a transaction created a security interest-a scheme established by the UCC to deal with this question in sales of accounts or chattel paper and in consignments. Therefore, we shall next consider the Code's treatment of leases, some of which do and some of which do not create security interests.

\section{The Code's TReatment of Leases}

In order to understand the Code's treatment of leases and the feasibility of proposed alternatives, such as a treatment of leases similar to that accorded sales of accounts and chattel paper or that accorded consignments, it is necessary to review briefly how leases are used. The great majority of leases of personal property serve the traditional purpose of chattel lease: they supply, for a price, temporary use of property. The price paid, in the form of rent, is for temporary use of an item which itself must be returned to the lessor at the end of the term - be that term a day, a week, six months, or thirty years. This obligation to return the leased item to the lessor is the distimguishing characteristic of a lease, just as an obligation to pay the full purchase price is the distimguishing characteristic of a sale.

Present article 9 problems generally arise when the parties denominate their instrument a lease but distribute the incidents of ownership in a manner customarily associated more with sellers and purcliasers than with lessors and lessees. Particularly in a long-tern lease the lessor-seller often demands that the lessee assume risks of loss which would normally fall on the shoulders of the lessor as an "owner" or of the other party as a buyer. For example, in a "full payout

122. Abandoned section 7-304 stated that rule simply. See pp. 938-39 supra. 
lease," the lessor insists that, regardless of intervening circumstances, the lessee will by the end of the lease term pay in the form of rent a full return on the lessor's investment in the leased property together with interest and profit, even though the leased property-which will at the time be returned to the lessor-still has substantial value. The lessor further deinands that rent payments contimue for the full duration of the lease term, whether or not the item continues to be used or usable; in fact, the lessor will insist that rent payments continue or even be accelerated if the leased item is destroyed. Voluntary termination is not allowed unless all costs, including interest and anticipated profits, are recovered at the time of termination.

The lessor will probably also insist that the lessee provide assurances that the residual will be worth more than an insubstantial amount. A chattel lessor could probably cite ancient and modern precedents in real estate law for shiftimg such risks to the lessee without giving the lessee the benefits of ownership; but the lessee may think that if he assumes the obligations of a buyer, lie should receive the benefits of a buyer. A lessee-purchaser may accede to the lessor's demands because as a practical matter the former party cannot obtain the use of needed equipment any other way or because a lease offers him real or imaginary advantages, usually for tax or accounting purposes. When a lessee agrees to accept the risks, he quite naturally recognizes that his lease payments will have amortized the lessor's cost, including interest and profit, by the end of the term. He will, as a result, often argue that the leased item should be made available to him at little or no cost at the end of the term. In a tax-oriented lease, ${ }^{123}$ where tax advantages to the lessor are crucial, the lessor's

123. We use the term "tax-oriented" lease to describe leases which are entered into primarily froin the standpoint of giving the supplier of money or goods advantages that he could not obtain as a lender of money or as a purchase money vendor. Those rights consist in either or both of the following: (a) a right of the lessor as owner to take the benefits of the investment tax credit, which would otherwise be available to the lessee; and (b) the right of the lessor to take accelerated depreciation. The effect of the tax credit is to give the lessor-owner a bonus (on certain equipment, seven percent of cost) otherwise available to the lessee. See INT. Rev. Code of 1954, $\S \S 38,46-50$. The effect of the right of the lessor to take accelerated depreciation is to shelter some of his taxable income from other sources. See id. $\$ 167$. Unlike the investment tax credit, the result is a deferral of taxes-in effect an interest-free loan from the United States. In return, the lessor usually gives the lessee the benefit of some or all of the tax savings in the form of a lower rental rate. An example: an airline which has all the depreciation it can utilize needs new equipment. If it were to buy the equipment, the investment tax credit and the benefits of accelerated depreciation would be wasted because of lack of offsetting taxable income. The lessor, on the other hand, has sufficient income from other sources to make full use of these tax advantages. The complications are very great and the tax-oriented lease is 
tax counsel will usually give a soft "no" to any such requests by the lessor out of fear that the transaction will consequently be classified as a sale and that those tax advantages to the lessor will thereby be lost. In such a case, there can be no deal unless the advantages of the lease to the lessee outweigh the lessor's objections to surrendering the value remaining at the end of the lease term. But where the lessor's tax considerations do not control, the bargaining continues. In the simplest case of this latter type, the lessee demands that title be transferred to him at the end of the lease or demands an option to buy the goods for one dollar or some other nominal amount, irrespective of the actual market value at that time. ${ }^{124}$ Or he may imsist on a right to renew from year to year in the period following the lease term at a rent considerably below the normal rental value. The variations are legion. The law is likely to be concerned not so much with the lessee's assumption of what should be the lessor's risks as it is with a lessee's obtaining rights more cominonly associated with the status of a buyer.

As "leases" take on the attributes of sales, it becomes necessary to distinguish the true lease from the disguised purchase, and we confine our attention at the moment to the resulting consequences under chattel security law. A true lease is not subject to any of the provisions of article 9, but a "non-true" lease is subject to all of article 9. A true lease also may require different accounting treatment and may produce different tax results than a sale denominated as a lease. Also, the obligations of a lessee would be treated differently in the event of his bankruptcy. Under section $70 \mathrm{~b}$ of the Bankruptcy Act, ${ }^{125}$ the trustee can elect to affirm or reject a lease or other executory con-

not one for the amateur. Tax-sheltered investments are particularly attractive to both parties where the lessor is in a position, because of taxable income from other sources, to make better use of tax advantages than the lessee can and where the lessor is willing to pay for those advantages in the form of a lower money cost in the rent formula.

124. The practice is old. Almost a century ago the United States Supreme Court had before it a case in which Illinois creditors attached a locomotive purportedly leased (apparently for one year) by the manufacturer. Under the terms of the lease, the lessee was allowed to purchase the locomotive on termination upon payment of ten dollars. The Supreme Court had no difficulty in holding that the transaction was a conditional sale, invalid against creditors because of failure to record under an Illinois statute. Hervey v. Rhode Island Loconotive Works, 93 U.S. 664 (1876). Citing previous authority, the Court found that rental payments were installment purchase payments equal to the value of the locomotive. 93 U.S. at 673. But an option to buy, without an obligation to pay the purchase price does uot convert a lease into a conditional sale. See WiLliston $\S 336$, at 526-29. Strangely, the one-dollar option still appears in the litigated cases. See Hawkland, supra note 2, at 471-75 (items 5, 14, 20).

125. 11 U.S.C. $\$ 110(b)(1970)$. 
tract. If the leased item is a fixture, section $70 \mathrm{~b}$ 's limits on the lessor's claim might apply. In every such conditional sale-lease case the question must be faced: how does one determine the difference between the two types of transactions-a true lease and a conditional sale? In light of the amount of UCC litigation and the volume of comment, making this judgment seems to be a difficult task.

But before struggling further with the problems inherent in distinguishing a true lease and a conditional sale from the standpoint of article 9, perhaps we should consider the possibility of avoiding the necessity of answering the lease-conditional sale question by treating all leases as though they created security interests. A short answer to this approach is that leases lacking the characteristics of conditional sales seem inappropriate candidates for apphication of the most essential features of article 9-the remedy provisions. In connection with the Code's treatment of accounts and chattel paper, we have discussed the basic problems involved in attempting to apply article 9's remedy provisions to commercial transactions which do not create security interests; and in that discussion we have seen that at least some modification of the remedy provisions was necessary when secured transactions were arbitrarily dubbed "security interests." Some such modification would surely be required if this simple answer were seriously considered for all leases.

The pattern established with sales of accounts and chattel paper could be followed by requiring an article 9 filing with respect to all leases and by applying the priority and the statutes of frauds provisions of article 9. Ideally, as a result, the difficult question of whether a particular lease constituted a true lease or a conditional sale would have to be faced only in those cases where a disagreement arises (usually between the parties) and results in the necessity of determining whether the reinedy provisions of part 5 of article 9 would apply. Since such controversies arise in relatively few cases, this treatment not only would have the merit of simphicity but also would entirely avoid in the bulk of all lease cases the article 9 question of whether, for security purposes, a transaction constituted a true lease or a conditional sale. And the accountants and tax counsel would be left to answer their related but differing questions.

Yet the question remains whether this article 9 pattern is practical with respect to leases. Perhaps because of the very fime line distinguishing a sale of accounts or chattel paper from an assignment for security, the Code's treatment of these devices is the most practical method of dealing with thein. A system which elimimates the need to decide the hard question of "is it a sale or a security interest," in all 
but the cases where the difference in remedy is material, has much to recommend it. It is submitted, however, that while the lease-conditional sale question is more difficult than the consignment-conditional sale determination, deciding whether a sale of accounts in fact creates a security interest is a more complex inquiry than either of the other two problems. ${ }^{126}$

Perhaps a more important-reason to excuse lease transactions froin what is presently required for all sales of accounts is the fact that the lessor can fully protect himself (though with perhaps more effort) by voluntarily doing what the accounts purchaser is required to $\mathrm{do}^{127}$-namely, by insisting upon a written agreement which the lessee signs and by filing a financing statement before the debtor-lessee gets possession of the leased iten. ${ }^{128}$ With sizable transactions, the burden should not be too great, especially when one considers the protection afforded. When frequently repeated transactions are involved, a single filing with adequate wording will avoid the necessity for constant refiling. New items may be added under a master lease in such a way as to reduce the paperwork. With small transactions, some risk may be assumed and a filing may not be inade.

It would seem that treatment similar to that now required for ac-

126. The test as to whether a consignment is a true consignment or a disguised security agreement should provide no difficulty except in establishing the bargain of the parties. If the consignee has only a power to sell as an agent of the consignor and retains the privileges of discharging his obligations by returning the goods, the arrangement is a consignment. If the "consignee" obligates himself to pay for the goods whether or not he sells them, he is no longer a consignee but a vendee or a conditional vendee. In most lease cases, the answer is only slightly harder-(a) has the lessee obligated himself to pay the purchase price and (b) lave the parties agreed that upon the lessee's payment of a price substantially equal to the value of the goods, the lessee becomes or has the option to become the owner of the property. If the option price is one dollar or a small percentage of the value, the transaction fits the UCSA's section 1(2) definition. The status of the transaction becomes less clear as the price becomes substantial. Similarly, other factors may make the answer less siniple. The more difficult questions would normally arise in complicated tax-oriented leases, but lessors for tax reasons insist on playing so safe that UCC questions are unlikely to arise.

We have noted above the harder question as to when an assignment of accounts is a secured transaction. See pp. 942-47 supra.

127. It may seem that this observation is inconsistent with the statement that compliance with filing rules by consignors is not likely to be overly difficult. Consignments, unlike leases, have a tendency to be repeat transactions between the same parties; and one filing is good for five years for a "type" of goods. Leases are less likely to be a repeat pattern: a lessor may either deal with different lessees or handle different types of goods with the same lessee.

128. UCC section 9-312(4) requires such filing in order to protect the purchase money secured party's priority. This rule assumes that the "lease" would be a purchase money security interest, if any. 
counts may not be justified for leases in light of the problems which such an approach might create, particularly for true short-term lessors. For example, adoption of the UCC's treatment of accounts and chattel paper would require an article 9 filing for all leases; but without soine troublesome exceptions, ${ }^{129}$ there are simply too many leases made every day for this procedure to be administratively or economically viable. As a second alternative, compliance could be excused for at least some short-term leases. However, there are certain short-term leases which may be of such a character that filing would be desirable; and as soon as one must distinguish between those where some comphance is appropriate and those where none is required, the simplicity of the rule is lost. Also, even with an exemption from the article 9 remedy provisions, designating all leases as security interests might raise serious problems (though it should not) with the characterization of the lease accorded for accounting and tax purposes. ${ }^{130}$

Mucli of the discussion above would apply equally to a third possible alternative: the Code could have required for leases something less than the compliance now required for accounts. It could have required, primarily for the benefit of creditors, public notice of all personal property leases similar to the notice mandated for all consignments under section 2-326. ${ }^{131}$ As with consigned goods, leased goods are in the possession of one who is not their owner. A creditor can be misled as to a debtor's ownership of equipment regardless of whether it was purchased subject to a purchase money obligation or is possessed under a lease. Requiring filing for all leases is certainly a conceivable solution, though one not traditionally followed. ${ }^{132}$ But treating leases like consignments would at least partially avoid the necessity for separating at the outset the true leases from those undertaken for security.

129. The commentators differ in their views as to what should be done. See, e.g., Leary, supra note 2, at 252 (all leases "for a substantial term" should be considered security interests); Peden, supra note 2, at 158 (all leases in excess of a prescribed minimum should be treated as security interests); Comment, supra note 2, at 13637 (the courts should interpret section 9-102 to apply broadly, but short-term leases should be excluded); 49 CoRNell L.Q. 672, 684 (1964) (UCC filing should be required for all leases, apparently with no exception).

130. See pp. 965-72 infra.

131. See pp. 946-54 supra.

132. For a thoughtful opinion on the rights of a lessor against a creditor of the lessee who had attached the lessor's slave, see Davis v. Turner, 4 Gratt. 422 (Va. Ct. App. 1848). Even in situations where, for tax considerations, the transaction is tailored to be a true lease at whatever cost to its lessee in loss of residual, careful lessors insist ou an article 9 filing "just in case" a referee should at soine future time have to consider whether the transactions could be held a lease for security. 
The Committee To Review Article 9 did not reconsider the UCC provisions relating to leases, including the issue of public notice; and, except for the new section $9-408,{ }^{133}$ no change in the treatment of leases was recommended in the committee's report. This section will probably encourage filing for leases claimed not to create security interests, because it affirmatively states what ought to be clear in any event-that an article 9 filing creates no inference that a lease or consignment has been executed for security. Moreover, a written lease will normally be found adequate to satisfy section 9-203's simple statute of frauds provisions. Therefore, by filing the lessor can protect himself against the eventuality that his "lease" will be called a conditional sale and can thereby insulate himself against lien creditors and most purcliasers from the lessee; moreover, the lessor will also avoid any inference that the instrument is not a lease for tax or accounting purposes. ${ }^{134}$ At the same time, more widespread filing should reduce the impact of probleins resulting from ostensible ownership by a lessee.

To sum up, it would be unwise to avoid the issue of which leases create security interests by declaring them all to be security interests. Unless the transaction closely approximates one traditionally handled as a security device, a lease transaction is not amenable to the application of the reinedy provisions of article 9 . It is obvious that a secured party cannot enforce his debtor's obligations by selling the "collateral" where the "collateral" is already owned by the "secured party." Therefore, at a mimimuin, something similar to the last two sentences which regulate the rights and obligations of the parties in the sinilar transaction of a sale of accounts would seem to be required, including perhaps a modification of section 9-506 on the debtor's right to redeem. If one takes out the lieart of a security interest (the reinedy provisions), query as to whether the exercise of denominating a device a security interest is worth the effort? One may further venture the conclusion that, for the same reason, a provision requiring a filing with

133. This provision provides:

A consignor or lessor of goods may file a financing statement using the terms "consignor," "consignee," "lessor," "lessee" or the like instead of the terms specified in Section 9-402. The provisions of this Part shall apply as appropriate to such a financing statement but its filing shall not of itself be a factor in determining whether or not the consignment or lease is intended as security (Section 1-201(37) ). However, if it is determined for other reasons that the consignment or lease is so intended, a security interest of the consignor or lessor which attaches to the consigned or leased goods is perfected by such filing. UCC $\$ 9-408$.

134. See pp. $965-72$ infra. Revenue Ruling 55-540, § 4.03, 1955-2 CuM. BuLL. 42, very properly makes recording or nonrecording immaterial in ascertaining tax consequences of the transaction. The writer is unaware of any accounting statements that would consider the recording or nonrecording of a lease as material in determining the proper accounting procedure to be accorcled that lease. 
respect to all leases and reaching the question of whether a lease is a true lease only when a dispute forces resort to article 9's remedy provision not only is of questionable wisdom but also is unlikely to be adopted in the foreseeable future, especially with the advent of the gentle hint and option of section 9-408. ${ }^{135}$

At least in some cases the question must be answered: which leases constitute disguised conditional sales and which do not? The question typically arises where a lien creditor of or purchaser from the "lessee" claims priority over the "Iessor" to the "leased" item by asserting that the "lease" is in substance a conditional sale and that the "lessee" is therefore a secured party who failed to protect his rights by complying with article 9 . The challenge may also come from another secured party: the lessor-seller may have neglected to file altogether, or he may have failed to file soon enough to comply with the requirements of section $9-312(4),{ }^{136}$ which protects the priority given to a purchase money security interest holder against a secured party who has filed earlier and whose security agreement covers this type of collateral. Or, should the lessor-seller attempt to reclaim the leased item from the lessee-debtor without conforming to the mandatory article 9 machinery regulating repossession and sale by secured parties, a lessee may assert that his lessor is really a secured party who must abide by these debtor-protective provisions of article $9 . .^{137}$

Once the question arises as to whether a transaction is a true lease or a conditional sale, standards for determination must be sought outside the actual provisions of the Code. Article 9 is hittle help in determining whether a lease is intended for security. And 1-201(37) itself gives only slight aid. It was noted above that in a comment to what was then section 8-102 (the predecessor of present section 9-102), the draftsmen in the fall of 1949 indicated that they left the question of when a lease or consignment becomes a conditional sale to what are now the first and second sentences of 1-201(37). But these sentences

135. As stated above, filing is standard practice with sophisticated lessors even where a transaction has met the rigorous standards necessary to obtain a tax ruling to that effect or an opinion of tax counsel experienced in tax aspects of leases. See note 132 supra. Section 9-408 should prompt the unsophisticated lessor to feel that he loses nothing by filing. He may, of course, retort that a provision in the UCC may not influence tax authorities or accountants.

136. Section 9-312(4) establishes the general rule for collateral other than inventory that the purchase money interest takes priority if it is perfected when the debtor receives possession of the collateral or within ten days thereafter.

137. It is conceivable but unlikely that a lessor who had caused coinpliance with article 9 to be made could find article 9 remedies more effective in a given case and assert that the lease was one for security. 
in section 1-201(37) identify only the minimal elements of a security interest. ${ }^{138}$ The previous discussion also emphasized that the somewhat tricky but perhaps accurate wording of the second sentence of 1-201(37) merely points out that a seller's reservation of title is limited to a security interest. This sentence does not say that a seller's reserved title is always a security interest, nor does it indicate what elements should be added to the reservation of title in order to constitute a security interest. ${ }^{138}$ As to when a would-be lessor is to be treated as a seller, section 1-201(37) of course is silent.

We are thus thrown back to earlier drafts of the Code and to pre-Code law. Fortunately, in this great bulk of "is it a lease or a conditional sale" cases, both pre-UCC law and earlier drafts of the present Code are reasonably clear. However, that law is muddied somewhat by the only sentences in section 1-201(37) which deal explicitly with the question of when a lease constitutes a security interest ${ }^{140}$ - the fifth and sixth. As we have seen, these last two sentences were added in the 1954-1956 revisions many years after the original Code draftsinen had considered section 1-201(37) complete. ${ }^{141}$ The fifth sentence merely repeats hornbook pre-Code law: simply because there is a title retention and an obligation that could be secured in every lease, a security interest is not automatically created. ${ }^{142}$ Even less helpful is the introductory clause of the sixth sentence, which merely states that whether a lease is intended for security depends on the facts of each case but gives no indication of what facts are pertinent or what law provides the standards to be used.143 Clause (a) of the sixth sentence, like the fifth sentence, states pre-Code law: the existence of an option to purchase at the end of the lease term cannot automatically be read as a security interest. ${ }^{144}$ Clause (b) of the sixth sentence, making a lease containing an option to purchase for nominal consideration or no additional consideration one for security, suggests even more questions. Suppose the lessor in a moment of weakness gave an option to the lessee to purchase the leased property at a nominal amount, even though the lessee at the time of exercise may not have

138. See pp. 922-36 supra.

139. See pp. 927-30 supra. In addition, it should be noted that the third and fourth sentences of section 1-201(37) have no connection with leases.

140. See pp. 931-36 supra.

141. See pp. 940-41 supra.

142. See pp. 931-32 supra.

143. See pp. 932-36 supra.

144. As Williston points out, it has long been the law that there can be a conditional sale, even where the lessee has an option to buy, if he is under no obligation to pay an amount substantially equal to the purchase price. Wirliston $\S 336$, at 528-29. 
previously paid in rents or otherwise an amount substantially equal to the market value of the leased item, as was required by the pre-Code UCSA for the transaction to be treated as a conditional sale. (This is an example of what practicing lawyers sometimes disdainfully call a "law school hypothetical." It assumes that the lessor cannot do his arithmetic.) Would the Code convert such a gift into a security agreement? Could the remedy provisions applicable to the secured party and the debtor be applied to such a case? What is the debtor's obligation? And what is "nominal" consideration under clause (b) of the sixth sentence? Nominal with respect to the total rent? To the lessor's purchase price? To the market value of the property? As of what time is "market" value to be determined? ${ }^{145}$ The practical questions which must be answered in applying this sole specific standard are not answered anywhere in the Code.

As noted previously, the definition of a conditional sale in section 1(2) of the UCSA answered many garden variety questions which seein to have puzzled referees and judges under the UCC. At a time when the predecessor of article 9 had resorted to separate parts for different types of financings, the definition provided in UCSA section 1(2) was fairly well adapted by section 7-403 with respect to leases for security (and completely by section 7-304 with respect to consignments for security). When these separate "Equipinent Liens" and "Inventory Liens" were merged into the all-encoinpassing "security interest" in the October, $1949 \mathrm{draft}$ in what then became article 8, these separate treatments of the lease-conditional sale and the consignment-conditional sale were dropped; but the draftsinen's intent to carry forward the essentials of the old law were clearly expressed in comment 1 to what was then section 8-102. However, when article 8 became article 9, even this comment was dropped. Perhaps, the draftsmen in 1949 were so steeped in pre-Code chattel security law that they considered it unnecessary to restate affirmatively this body of law which had long been settled. We therefore follow the suggestion of one of the Code's chief draftsinen, Professor Gilmore, and read the first and second sentences of section 1-201(37) by looking back to the Code's lineal ancestor-conditional sales law, and particularly the UCSA-for guidance. Because this source of standards has been fully explored by other commentators, ${ }^{146}$ we do not treat the UCSA here.

145. Pre-Code and Code cases, as well as the accountants' formulations, put the emphasis on market value at the time of the exercise of the option as reasonably estimated by the parties at the imception of the transaction. See Accounting Principles Board Opinion No. 5, supra note 59.

146. See Note, Acquisition of Industrial and Commercial Equipment Through Leas- 
Furthermore, while the text and cases of the UCSA may be of some help, the history of the drafting of the Code's provisions on leases leaves some unanswered problems as to just how much UCSA precedent is good law in certain areas. We can assume that the Code accepted the concept of abandoned section 7-403 that a lease is a lease for security, even where title does not pass, if the lessor can compel the lessee to extend the lease for the full life use. ${ }^{147}$ It would seem that under both UCSA section 1(2) and UCC section 1-201(37), the lessee can "become the owner" for no coinpensation other than that required under the lease and, therefore, that the transaction is a conditional sale or a lease for security. Here the lessee has put himself in a position where the lessor can as a practical matter force him to pay an amount presumably equal to the purchase price. This situation would seein to fulfill both the requirements of section 1(2) of the UCSA and those of the first sentence of 1-201(37) - a property interest and an obligation exist.

Yet what of the situation where the lessee has the option to extend for the full useful life, but he has no obligation to do so and there exists no power in the lessor to so obligate him? This transaction appears to create a security interest if the situation is viewed from the standpoint of creditors who are entitled to attach the "leased" equipment in the absence of statutory protection for the lessor-secured party who claims an interest or if we ascertain that the debtor-lessee has acquired such an equity interest that he can be deprived of it only in accordance with the debtor-protective provisions of part 5 of article 9. However, is there a sufficient "obligation" under the first sentence of section 1-201(37)? There appears to be no obligation substantially equal to the value of the goods. But do we read this term "obligation" in the first sentence of 1-201(37) as measured by section 1(2) of the UCSA?

And, under UCSA section 1(2), did the lessee "become the owner" where he never acquired title but where he had a right under the lease to use the property for its full (or substantially full) life? Both the UCSA and section 1-201(37) use the phrase "become the owner." To "become the owner" can be more or less than to acquire title.

ing Arrangements, 66 YALE L.J. 751 (1957); authorities cited note 49 supra. Many UCC cases are well reasoned; some are not. In any event, they have been reviewed by Leary, Hawkland, Peden, Stroh, and the student writers mentioned previously. See authorities cited note 2 supra.

147. But the comments to abandoned section $7-403$ indicate that the draftsmen of that section apparently were in doubt as to whether the UCSA's section 1(2) covered such cases. See May, 1949 Draft § 7-403, Comment 1. 
And for the purpose of determining whether the "lessee" has acquired enough of the incidents of ownership to demand that his creditors be allowed to attach, it is important to realize that unless statutory protection is given to the lessor-secured party's interest, title may be less important than ownership. Obviously, some, but not all, of these questions are easily answered by reference to pre-UCC conditional sales law. With so many questions left unanswered by the Code and pre-Code law, it is natural to look to the standards established by other disciplines-tax and accounting - which deal daily with leases and which are constantly faced with the question of wliether a transaction is in fact a lease or a conditional sale.

Tax counsel is often confronted with the necessity of making the determination of whether a transaction will be treated as a lease or a conditional sale for tax purposes, because tax treatinent may vary greatly depending on whether the transaction is characterized as a sale or a lease. Because tax consequences often will determine the economic feasibility of a particular transaction and since tax counsel are frequently faced with the lease-sale dilemma as a result, the chattel security lawyer may find some assistance and guidance in the tax literature when attempting to ascertain whether a lease is one for security. The analysis in much of the tax hiterature is likely to be more penetrating than is that in most UCC lease cases. However, the literature on the lease-sale is so voluminous that it is beyond the scope of this Article to review it in any detail. Rather, the ensumg discussion shall focus on some basic concepts which the tax literature reveals as essential in naking a determination of whether a lease is actually a conditional sale.

Section 162(a) (3) of the 1954 Internal Revenue Code allows, as did its predecessors under earher versions, ${ }^{148}$ rent deductions from gross incoine only where the lessee is acquiring neither title to nor an equity in the leased property. If the lessee is receiving either title to or an equity in the property, he is considered a purchaser and naturally cannot deduct rent for his own property. In making this necessary lease-sale determination, tax counsel is likely to begin with Revenue Ruling 55-540.149 That ruling, like section 1-201(37), indicates that

148. See Act of May 28, 1938, ch. 289, $\S 23$ (a) (1), 52 Stat. 460 (now INT. Rev. CODE of 1954, \$ 162(a)(3)).

149. This ruling states in part:

Whether an agreement, which in form is a lease, is in substance a conditional sales contract depends upon the intent of the parties as evidenced by the provisions of the agreement, read in the light of the facts and circumstances existing at the time the agreement was executed .... [A]n intent warranting treatment of a transaction for tax purposes as a purchase and sale 
each case is to be determined on its facts; nevertheless, the ruling does set forth guiding principles, in which process it incorporates much old conditional sales law. In four-and-one-half closely printed pages (as contrasted with four sentences in section 1-201(37)), the Commissioner gives some helpful indications as to when a purported lease is to be treated as a sale; but the Commissioner's recognition of the need to supplement his four-and-one-half page ruling does not encourage one to think the draftsmen of article 9 could do a substantially comparable job within the framework of article 9.

At the time of this writing, the use of many millions (and probably billions) of dollars' worth of equipment is being obtained through a medium of tax-oriented leases where the ability of the lessor to take accelerated depreciation and obtam the Investment Tax Credit are so crucial that the lease will not be entered into without a ruling by the Commissioner on this point, or at the very least, an unqualified opinion by tax counsel, who necessarily must err only on the side of caution. ${ }^{150}$ Tax counsel and adminstrators have developed a lore of their own for distinguishing a true lease from a disguised sale. One point of interest is their emphasis upon the necessity for the lessor's retention of a residual of significant and ineasurable value. Although this element is seldoin stressed as such in chattel security hiterature, ${ }^{151}$ it is suggested that if UCC draftsmen ever deem it feasible to devise some-

rather than as a lease or rental agreement may in general be said to exist if ... one or more of the following conditions are present:

(a) Portions of the periodic payments are made specifically applicable to an equity to be acquired by the lessee... .

(b) The lessee will acquire title upon payment of a stated amount of "rentals" whicli under the contract he is required to make . . . . .

(c) The total amount which the lessee is required to pay for a relatively slort period of use constitutes an inordinately large proportion of the total sum required to be paid to secure the transfer of title

-. (d) The agreed "rental" payments materially exceed the current fair rental value...

(e) The property may be acquired under a purchase option at a price which is nominal in relation to the value of the property at the time when the option may be exercised, .... or which is relatively small when compared with the total payments which are required to be made

(f) Some portion of the periodic payments is specifically designated as interest or is otherwise readily recognizable as the equivalent of interest. Rev. Rul. 55-540, \& 4.01, 1955-2 CuM. BuLr. 41-42.

It is suggested that one seldom meets the situations covered in clause (a). Furthermore, clause (f) would be irrelevant for security purposes, and query as to why it is important for any other purposes?

150. See p. 965 supra.

151. But cf. In re Aurora Gaslight, Coal \& Coke Co., 64 Ind. App. 690, 697-98, 113 N.E. 1012, 1015 (1916); Smull v. Delaney, 175 Misc. 795, 799, 25 N.Y.S.2d 387, 393-94 (Sup. Ct. 1941); Powers v. Trustees of Caledonia County Grammar School, 93 Vt. 220, 232, 106 A. 836, 841 (1919). 
thing better than either old UCSA section 1(2) or abandoned section $7-403$, study should be directed toward the possibility of devising a formula based on the value of the residual to be returned at the end of the lease term. A rule of thumb in tax rulings and in super-cautious opinions of lessors' tax counsel is (1) that the lease must come to an end at a time when at least two years or twenty percent of the useful life of the leased itein remains, and (2) that this residual must be valued at not less than fifteen percent of the purchase price. The lessor's tax counsel is likely to insist that there be no options, or only an option to purchase at the inarket value as determined when the option is exercised. This position is based on the premise that risk of an increase or decrease in value of the residual is an incident of the lessor's ownership and that he should, therefore, bear this risk.

Standards applied in tax rulings and in counsel's opinions that must err only on the side of caution are not necessarily those which will be applied if the transaction terminates in litigation over taxes. In both tax rulings and such unqualified tax opinions, the requested result is not assurance that the taxpayer would win a litigable case, but rather assurance that the issue is sufficiently clear that no litigation will be commenced. Further, there are limitations on the validity of any analogy or application of actual tax cases in dealing with lease questions under section 1-201(37). There are basic differences in the statutes being interpreted. For example, the Uniform Commercial Code nowhere says that a transaction is one for security where the lessee acquired "an equity" in the leased item, as is the case under Internal Revenue Code section 162(a)(3), dealing in deductability of rent payments. Also, in this determination of the lessee's equity, there are differences between Tax Court opinions and the provisions of the UCSA as to the role played by econonic considerations, apart from the question as to how economic factors indicate the probable intent of the parties. While the intention test of 1-201(37) may be a weak reed, the language of the section demands the use of an intention test. Little weight need be given to the parties' use of the word "lease" and the like; the intent of the parties should be determined according to the effect of their actions.

Further, that intent must necessarily be judged in light of the surrounding circumstances at the time of entering the transaction and not at a later date. At least three courts of appeal in tax $\operatorname{cases}^{152}$ have

152. See Western Contracting Corp. v. Commissioner, 271 F.2d 694 (8th Cir. 1959); Breece Veneer \& Panel Co. v. Commissioner, 232 F.2d 319 (7th Cir. 1956); Benton v. Commissioner, 197 F.2d 745 (5th Cir. 1952). 
reached a conclusion in harmony with section 1-201(37)'s focus on the intention of the parties at the inception of the transaction. On the other hand, the Tax Court, when determining in a nuunber of cases whether the lessee was acquiring an equity in the leased property and therefore was not entitled to a rent deduction, considered facts existing at the end of the lease term and applied a primarily economic test. ${ }^{163}$ The key to the lease-sale question in these Tax Court cases was whether the transaction, regardless of intention, in fact gave the lessee the equivalent of a purchase. Frequently, but not always, the result of an objective intent test and the so-called economic factors test are the same. However, section 4 of Revenue Ruling 55-540, ${ }^{154}$ in keeping with section 1-201(37), states that the intent of the parties at the initiation of the transaction is controlling on the question of whether a lease was created. As a result of these divergencies, while it remains true that tax law can by analogy be instructive to the chattel security lawyer, care inust be taken in applying tax law, especially the super-cautious standards applied by counsel in obtaming tax rulings on UCC probleins.

Just as tax counsel inust determine whether a certam transaction will be taxed as a lease or a conditional sale, accountants must deterinine whether a transaction is actually a lease or a purchase in order to give the item appropriate treatment in the lessor's and lessee's balance sheets and income statements. In the post World War II period, when leasing became very popular and when accounting standards were unore lax, many "leases" which were in fact conditional sales were kept off the lessee's balance sheet-both on the asset and, more importantly, on the liability sides.

In his 1962 study, Professor Myers recommended that all leases be given appropriate balance sheet treatment if the lessee was acquiring a "property right" in the leased goods. ${ }^{155}$ In Opimon Number

153. Some Tax Court cases have considered what the parties actually did, rather than what it was they apparently intended to do at the inception of the transaction. See Western Contracting Corp., 27 P-H Tax Ct. Mem. II 58,077 (1958), 271 F.2d 694 (8th Cir. 1959); Breece Veneer \& Panel Co., 22 T.C. 1386 (1954), rev'd, 232 F.2d 319 (7th Cir. 1956); H.T. Benton, 19 P-H Tax Ct. Mem. II 50,223 (1950), rev'd, 197 F.2d 745 (5th Cir. 1952). Courts of appeal appear to disagree. Revenue Ruling 55-540, § 4.01, 1955-2 CuM. BuLl. 41, states that the agreement should be read "in the light of circumstances existing at the time the agreement was executed." The comparison of the option price must be with market value at the time of exercise, as determincd at the inception. Id. $\$ 4.01$ (e), 1955-2 CuM. Bull. 42. Accountants are in accord in both points. Accounting Principles Board Opmion No. 5, supra note 59.

154. See note 149 supra.

155. J. Myers, Reporting of Leases in Financial Statements 4 (1962). 
$5^{156}$ of the Accounting Principles Board, the APB was unwilling to go this far; but the accountants attempted to explain when the property subject to a lease should be stated as an asset and when the future "rent" should be listed as a liability. In paragraph 5 the Board states that the "distinction depends on the issue of whether or not the

156. Accounting Principles Board Opinion No. 5, supra note 59, states in part:

5. The Accounting Principles Board has considered the recommendations and the supporting argument presented in Accounting Research Study No. 4. The Board agrees that the nature of some lease agreements is such that an asset and a related liability should be shown in the balance sheet, and that it is important to distinguish this type of lease from other leases. The Board beheves, however, that the distinction depends on the issue of whether or not the lease is in substance a purchase of the property rather than on the issue of whether or not a property right exists. The Board beheves that the disclosure requirements regarding leases contained in Accounting Research Bulletin No. 43, Chapter 14, should be extended, and the criteria for identification of lease agreements which are in effect installment purchases of property should be clarified. The Board also believes that accountmg for gains and losses on sale-and-leaseback transactions should be specifically dealt with in this Opinion.

-..

10. The property and the related obligation should be included as an asset and a liability in the balance sheet if the terms of the lease result in the creation of a material equity in the property. It is uulikely that such an equity can be created under a lease which either party may cancel unilaterally for reasons other than the occurrence of some remote contingency. The presence, in a noncancelable lease or in a lease cancelable only upon the occurrence of some remote contingency, of either of the two following conditions will usually establish that a lease should be considered to be in substance a purchase:

a. The mitial term is materially less than the useful life of the property, and the lessee has the option to renew the lease for the remaining useful life of the property at substantially less than the fair rental value; or

b. The lessee has the right, during or at the expiration of the lease, to acquire the property at a price which at the inception of the lease appears to be substantially less than the probable fair value of the property at the time or times of permitted acquisition by the lessee. In these cases, the fact that the rental payments usually run well ahead of any reasonable measure of the expiration of the service value of the property, coupled with the options which permit either a bargain purchase by the lessee or the renewal of the lease during the anticipated useful life at bargain rentals, constitutes convincing evidence that an equity in the property is being built up as rental payments are made and that the transaction is essentially equivalent to a purchase.

…

11. The determination that lease payments result in the creation of an equity in the property obviously requires a careful evaluation of the facts and probabilities surrounding a given case. Unless it is clear that no inaterial equity in the property will result from the lease, the existence, in connection with a noncancelable lease or a lease cancelable only upon the occurrence of some remote contingency, of one or more circumstances such as those shown below tend to indicate that the lcase arrangement is in substance a purchase and should be accounted for as such.

a. The property was acquired by the lessor to meet the special needs of the lessee and will probably be usable only for that purpose and only by the lessee.

b. The term of the lease corresponds substantially to the estimated useful life of the property, and the lessee is obligated to pay costs such as taxes, insurance, and inaintenance, which are usually considered incidental to ownership.

c. The lessee has guaranteed the obligations of the lessor with respect to the property leased.

d. The lessee has treated the lease as a purchase for tax purposes. 
lease is in substance a purchase of the property rather than on the issue of whether or not a property right exists."157 In paragraph 9 the Board nakes it clear that it is talking about lease agreements which "are essentially equivalent to installment purchases of property. In such cases, the substance of the arrangement, rather than its legal form, should determine accounting treatunent." ${ }^{158}$ In paragraphs 10 and $11,{ }^{169}$ the Board attempts to set out these determining factors. In paragraph 10 the Board talks not about lease agreements "essentially equivalent to installment purchases" but in terms of "creation of a material equity in the property." Under clause $a$ of paragraph 10 , a lease should be given balance sheet treatment if the initial term is materially less than the useful life and the lessee has the option to renew for the remaining useful life at substantially less than the fair rental value. Under clause $b$, that balance sheet treatment should be required if "the lessee has the right, during or at the expiration of the lease, to acquire the property at a price which at the inception of the lease appears to be substantially less than the probable fair value of the property at the time or times of permitted acquisition by the lessee." As a practical inatter, these tests would seem to accord with the substance of UCSA section 1(2): ${ }^{160}$ they imply the payment of an amount equivalent to the value of the property. Only a lessor who had failed to do his arithmetic would grant the kind of option to renew referred to in clause $a$ or the type of option to purchase mentioned in clause $b$, unless in fact such payinents had been required.

Paragraph 11, however, is puzzling. It applies some tests which would appear to have hittle bearing upon the question of whether or not the lessee has "acquired an equity or has entered into a lease agreement essentially equivalent to an imstallment purchase." At least for chattel security purposes, it should be immaterial whether the "lessee is obligated to pay costs such as taxes, insurance and maintenance, which are usually considered incidental to ownership." Whether the lessee pays such costs under lump suin payinents called rent or whether he is obligated to pay trem as individual items should make no difference. Furthermore, the application of the $a, b, c$, and $d$ tests of paragraph 11 is puzzling. They apply "[u]nless it is clear that no material equity in the property will result from the lease . . . " It would seem that this is the very point which, under paragraph 10 , the accountants are attempting to establish.

157. See note 156 supra.

158. 1 APB Accounting Principles $\$ 5351.09$ (current text).

159. See note 156 supra.

160. For the text of UCSA § 1(2), see pp. 937-38 supra. 
The accountants' Opinion Number 5 does not purpose to be complete, although it does treat the aspects most likely to face the chattel security lawyer. It was supplemented in May, 1966 by Opinion Number 7 on "Accounting for Leases in Financial Statements of Lessors." 101 This in turn was supplemented in November, 1972 by Opinion Number 27, entitled "Accounting for Lease Transactions by Manufacturers or Dealer Lessors." "Opinion Number 27 amended some of the provisions of Number 7. But from the standpoint of one looking for rules that can be developed as a result of sufficient time and thought, the most discouraging APB offering is Opinion Number $31 .{ }^{163}$ In this opinion, the accountants indicate that there is not yet general agreeinent as to the appropriateness of some rules in previous opinions, some of which are changed by Nunber 31 . The Board also states that it is reluctant to take affirmative stands because the whole subject has been turned over to its successor, the Financial Accounting Standards Board. On the practical side, it is to be noted that even with the careful study which these opinions indicate the APB has given the subject, the accountants are not prepared to say that their rules result in the same treatment of the same transaction by the lessor and the lessee. In fact a partner in one of the principal accounting firms reported in 1972 that "for practical reasons lessees and lessors do not necessarily account for a given lease in the same inanner. Judgments differ based upon different perspectives. Furthermore, existing guides in accounting are not consistent. Thus, for example, a substantial number of jet aircraft presently in use are not reported as assets on the financial statements of any company. Airline lessees view them as true leases, while lessors treat the leases as substantive sales, at least for accounting purposes."164

Chattel security lawyers who must struggle with the question of when a lease becomes a disguised conditional sale can profitably review the accounting literature; but a set of rules produced after many years of study which result in one conclusion from the standpoint of

161. 1 APB Accounting Principles $\$ 4051$.

162. Id. at $\S 4052$.

163. Id. at $\S 5352$.

164. See Wyatt, supra note 6 , at 502. It should be noted that the Securities and Exchange Commission has amended its accounting regulations to require (subject to certain exceptions for nonmateriality) disclosure by lessees of the present value of "financing leases" and the impact on net income due to the capitalization of such leases. For the purpose of these amendments, a "financing lease" is defined as a lease which during the noncancelable period, either covers seventy-five percent of the economic life of the property or has terms which assure the lessor a full recovery of the fair market value of the property at the inception of the lease plus a reasonable return on that investment. SEC Release No. 5428. 
the lessor and another conclusion from the standpoint of the lessee in the same transaction do not encourage a lawyer to think that he can find ready-made answers from even long and serious studies by a related discipline. We have seen that long-established Revenue Ruling 55-540 ${ }^{165}$ acknowledges the need for further clarification after setting out its rules im far more space than would be appropriate im the UCC. We have seen also that the rules of thumb used by tax administrators and by counsel schooled in the field of tax-oriented leasing are not automatically transferable to the legal question of when a lease is one for security and when not. ${ }^{168}$ Surely one could not adopt such standards.

A further word, however, may be said with respect to the emphasis upon a residual as a test of a true lease. A lease is basically an arrangement which provides for a payment called rent and which looks towards the return of the leased property to the lessor at a time when it still has some residual value. Where the question is whether or not the lessor has the right to deduct depreciation on the leased item, it may well be appropriate to say that the lessor should get back the property while it still has some useful life. Such a test would seem overly harsh if applied to a determination of when a lease is one for security. It could well be that an intelligent lessor would be content to receive his goods in a state where their value, though not insubstantial, rested entirely upon the salvage value. In the case of a chattel security lease, the requirement that the residual be worth at least fifteen percent of the original cost again may be inappropriate: such a rule may be too harsh a formula for determining whether the lessor is getting back at the end of the term something of not insignificant value. If one were

165. See pp. 965-66 supra.

166. One tax authority summarizes these under 8 topics as follows:

(1) At least a 20 percent initial cquity investment by the lessor;

(2) At least some cash flow to the lessor (stated to be at least 4 percent);

(3) A residual value at the end of the lease term of at least 15 percent of the original cost;

(4) A useful life of the leased asset at least 2 years longer than the lease term (or, if less, at least 20 per cent longer);

(5) Consistency between the useful life claimed for depreciation and investment credit purposes. (The Revenue Act of 1971 amended $\& 46(\mathrm{c})(2)$ to provide that the useful life of any property for purposes of the investment credit shall be the useful life used in computing depreciation.);

(6) Level rental payments;

(7) No option to purchase or extend the lease term, unless based upon fair market value at the time of exercise;

(8) No option to extend the lease term for the full useful life.

Baskes, supra note 5 , at 485 .

Items (1), (2), (5), and (6) have no bearing upon the chattel security deternination of lease versus security interests. We have commented on (3), residual value. Items (7) and (8) are, of cóurse, in point but are aspects of the lessor's residual value. Should there be an option to purchase the lease at less than inarket value or to extend for full useful life, the lessor's residual is to that extent reduced. 
to attempt to distinguish a true lease from a disguised purchase, it might well be that the most fruitful single test would be the presence or absence of a meaningful residual. But in the meantime those who must determine whether a lease is a conditional sale will probably find more help in UCSA section 1(2) than in the various rulings by the Commissioner of Internal Revenue, the APB opinions, or the rules of thumb used by the tax administrators and tax counsel in determining when a transaction is so clearly a lease that hitigation about it is unlikely to arise.

Within the limits of space ordimarily allowed to draftsmen of statutes (in fact, in one sentence), the UCSA draftsman has made it clear that where the lessee has agreed to pay an amount substantially equal to the value of the goods of which he is to become the owner (or has the option to become the owner), the parties have entered into a conditional sale agreement. But both conditions must exist for the remedy provisions of a chattel security system to function.

If the author is allowed to make one suggestion, it is that comments to section 1-201(37) be amended to carry forward the substance of the cominents to later abandoned section 7-403, which clearly indicate that the source of the lease-versus-conditional sale provisions is pre-Code conditional sales law. ${ }^{167}$

167. See notes 74-77 supra and accompanying text. 
